Working Paper

in Economics and

Development Studies

Department of Economics

Padjadjaran University

No. 201602

\title{
The Political Economy of Teacher Management in Decentralized Indonesia
}

Andrew Rosser

(University of Adelaide)

Mohamad Fahmi

Universitas Padjadjaran

Desember, 2016 
The Political Economy of Teacher Management in Decentralized Indonesia

\author{
Andrew Rosser ${ }^{1}$ \\ Mohamad Fahmi ${ }^{2}$
}

Keywords: political economy, education, teachers, teacher management, Indonesia

JEL Classifications: D73, H75, I28, P16

${ }^{1}$ University of Adelaide (University of Melbourne from February 2017).

2 Padjadjaran University. 


\section{Acknowledgements}

We wish to thank Ikhfan Haris, Ben Satriatna and Deri Mardiana for their assistance during fieldwork for this study. We also wish to thank Samer Al-Samarrai, Jerry Strudwick, Tazeen Fasih, Fasli Jalal, Yasuhiko Matsuda, Andy Ragatz, Halsey Rogers, Javier Luque, Susiana Iskandar, Joanne Dowling, Santi Savitri, and Simon Milligan for providing useful feedback on the study design and early results and an earlier draft of the paper. We also want to thank Sumarna Surapranata, Director General for Teacher and Education Personnel, for his review of the paper. Finally, and most importantly, we wish to thank the numerous government officials, academics, donor officials, journalists, teachers, teacher and NGO activists and other individuals who gave up their time to be interviewed, particularly in our four focus regions. The views and opinions expressed in this paper are those of the authors only. DFAT and the World Bank do not accept legal liability for material contained in this document. 


\title{
Acronyms and Abbreviations
}

\author{
ACER \\ bansos \\ Baperjakat \\ Bappenas \\ BERMUTU \\ BKD \\ BKDD \\ BOS \\ BPK \\ BPKP \\ bupati \\ CBT \\ CPNS \\ DAK \\ dana bagi hasil \\ dana perimbangan \\ Dapodik \\ DAU \\ dewan pendidikan \\ DFAT \\ Australian Council for Education Research \\ social assistance \\ Advisory Board for Position and Rank \\ Agency for National Development Planning / National \\ Ministry of Development Planning \\ Better Education through Reformed Management and \\ Universal Teacher Upgrading \\ Badan Kepegawaian Daerah, Regional Civil Service \\ Agency \\ Badan Kepegawaian Daerah dan Diklat Regional Civil \\ Service and Training Agency \\ Bantuan Operasional Sekolah, School Operational \\ Assistance \\ State Financial Audit Agency \\ State Finance and Development Supervision Agency \\ district head \\ computer-based competency test \\ civil service candidate \\ Dana Alokasi Khusus, Special Allocation Funds \\ Revenue Sharing Funds \\ Funds provided by the central government transfers to \\ regional governments to enable the latter to carry out their \\ functions under decentralization. \\ MoEC education database \\ General Allocation Funds \\ District-level Education Boards \\ Department of Foreign Affairs and Trade (Australia)
}




\begin{tabular}{|c|c|}
\hline Dinas & local government agency \\
\hline di-nonjob-kan & $\begin{array}{l}\text { shifted from powerful positions within the dinas to ones } \\
\text { where they have nothing to do }\end{array}$ \\
\hline dinas pendidikan & District Office of Education \\
\hline DPR & Dewan Perwakilan Rakyat: national parliament \\
\hline DPRD & Dewan Perwakilan Rakyat Daerah: regional parliament \\
\hline FAGI & Independent Teachers Action Forum \\
\hline Fatayat & a women's organization that is part of Nahdatul Ulama \\
\hline FGII & Independent Teachers’ Forum \\
\hline FKGH & Honorary Teachers’ Communication Forum \\
\hline FSGI & $\begin{array}{l}\text { Federasi Serikat Guru Indonesia: Indonesia Federation of } \\
\text { Teacher Union }\end{array}$ \\
\hline formasi guru PNS & $\begin{array}{l}\text { the number and type of new civil servant teachers awarded } \\
\text { to regions by the central government each year }\end{array}$ \\
\hline GNI & Gross National Income \\
\hline Golkar & $\begin{array}{l}\text { the New Order's electoral vehicle, now one of the } \\
\text { country's main political parties. }\end{array}$ \\
\hline gugus & group, cluster \\
\hline Guru & teacher \\
\hline guru honda/honor daerah & honorary teacher appointed by regional government \\
\hline guru honor & honorary teacher \\
\hline guru inpres & civil servant teachers appointed under the Inpres scheme \\
\hline guru PNS & civil servant teacher \\
\hline guru tetap yayasan & permanent teacher at a private school \\
\hline ICW & Indonesia Corruption Watch \\
\hline IGHI & Indonesian Honorary Teachers’ Association \\
\hline IKIP & teacher training college \\
\hline
\end{tabular}




\begin{tabular}{|c|c|}
\hline IMF & International Monetary Fund \\
\hline Infak & spending in the name of Allah, a form of charity \\
\hline juknis & petunjuk teknis, technical guidelines \\
\hline kabupaten & district \\
\hline kepala sekolah & school principal \\
\hline KKGSD & Primary School Teacher Working Groups \\
\hline komisi & parliamentary commission \\
\hline komite sekolah & school committee \\
\hline Kota & municipality \\
\hline KPK & Anti-corruption Commission \\
\hline KPKMA & Municipality A Education Coalition \\
\hline KTSI & Indonesian Honorary Employees Community \\
\hline $\mathrm{LBH}$ & Lembaga Bantuan Hukum: Legal Aid Foundation \\
\hline LMPTK & Quality Improvement of Teachers and Education Personnel \\
\hline LPTK & Teacher Training Institutions \\
\hline LSM plat merah & an NGO that is closely linked to government \\
\hline Mahkamah Konstitusi & Constitutional Court \\
\hline Masjid Agung & Grand Mosque \\
\hline MenPAN & Ministry for the Empowerment of the State Apparatus \\
\hline MGMP & Subject Teachers Deliberative Groups \\
\hline MKKS & School Principal Working Deliberative Group \\
\hline MKPS & School Supervisor Working Deliberative Group \\
\hline MoEC & $\begin{array}{l}\text { Ministry of Education and Culture (Kemendikbud, } \\
\text { previously named MoNE) }\end{array}$ \\
\hline MoNE & $\begin{array}{l}\text { Ministry of National Education (Kemendiknas, changed } \\
\text { later into MoEC) }\end{array}$ \\
\hline
\end{tabular}




\begin{tabular}{|c|c|}
\hline mono-loyalty & $\begin{array}{l}\text { a policy requiring all civil servants to be loyal to the } \\
\text { government }\end{array}$ \\
\hline MoRA & Ministry of Religious Affairs (Kemenag) \\
\hline Muhammadiyah & $\begin{array}{l}\text { a leading Islamic social organization, generally considered } \\
\text { modernist in orientation }\end{array}$ \\
\hline Nahdatul Ulama & $\begin{array}{l}\text { a leading Islamic social organization, generally considered } \\
\text { traditionalist in orientation }\end{array}$ \\
\hline New Order & $\begin{array}{l}\text { the name of the regime that governed Indonesia from } 1965 \\
\text { to } 1998\end{array}$ \\
\hline NGO & non-government organization \\
\hline Ojek & motorbike taxi \\
\hline Pancasila & literally, five principles. The state ideology \\
\hline PDI-P & Indonesian Democratic Party of Struggle \\
\hline pengawas & school supervisor \\
\hline perbup & bupati regulation \\
\hline perda & regional regulation \\
\hline Persatuan Umat Islam & Islamic Community Association \\
\hline PGRI & $\begin{array}{l}\text { Persatuan Guru Republik Indonesia: Indonesian Teachers } \\
\text { Union, the major teacher union }\end{array}$ \\
\hline PISA & Programme for International Students Assessment \\
\hline PKS & Prosperous Justice Party \\
\hline PNS & civil servant \\
\hline politisasi & politicization \\
\hline preman & street thug, gangster \\
\hline Prodep & $\begin{array}{l}\text { An Australian government-funded training program for } \\
\text { school principals and supervisors }\end{array}$ \\
\hline PTUN & State Administrative Court \\
\hline rombel & study group/class \\
\hline sekda & Regional Secretary, the head of the local civil service \\
\hline
\end{tabular}




$\begin{array}{ll}\begin{array}{l}\text { sekolah favorit } \\ \text { sekretariat }\end{array} & \begin{array}{l}\text { popular schools } \\ \text { SKB 5 Menteri }\end{array} \\ \text { SKTM } & \text { Five Ministerial Decree (on Teacher Management) } \\ & \begin{array}{l}\text { Surat Keterangan Tanda Miskin, a letter confirming that } \\ \text { one is poor }\end{array} \\ \text { SMA } & \text { senior secondary school } \\ \text { SMERU } & \text { a leading Indonesian private research institute } \\ \text { SMK } & \text { vocational senior secondary school } \\ \text { SPG } & \text { Teacher Education School } \\ \text { Surat Edaran } & \text { Circulating Letter } \\ \text { Tim Penilaian Akhir } & \text { Final Assessment Team } \\ \text { Uji Kompetensi Guru } & \text { Competency Test for Teachers } \\ \text { UNCEN } & \text { Cendana University } \\ \text { Upeti } & \text { tribute to leaders/officials paid by subjects } \\ \text { UPTD } & \text { Unit Pelaksana Teknis Daerah, agency branch } \\ \text { USAID } & \text { United States Agency for International Development }\end{array}$




\section{Introduction}

Since the early 2000s, Indonesia has dramatically increased spending on education in line with a new Constitutional requirement ${ }^{3}$ for the national government and regional governments ${ }^{4}$ to allocate at least 20 percent of their respective budgets to education. Between 2001 and 2012, public education spending increased from 2 percent of Gross National Income (GNI) to 4 percent. ${ }^{5}$ This increased spending has contributed to significant improvements in children's access to primary and junior secondary education, particularly through the funding of a new national school grants program (BOS) covering the operational costs of basic education and, in so doing, helping to realize the government's long-standing commitment to free basic education. However, it appears to have contributed little to improved student learning outcomes. While Indonesian children are starting school earlier and staying in school longer, they do not appear to be learning more. The country's performance in international standardized tests such as the Program for International Student Assessment (PISA) has improved little since the early 2000s and remains poor relative to neighboring countries. A recent World Bank (2015: 3) study concluded: 'The bottom line seems to be that, despite all the extra spending, nothing major has changed in the performance of Indonesia's school children'.

This outcome is related in part to problems of teacher management. Indonesia has plenty of teachers-around 3 million by one estimate (The Economist 2014). According to USAID's Prioritas program (2015), an initiative specifically concerned with teacher management, this gives Indonesia one of the most enviable teacher-student ratios in the world: for instance, with 1 teacher for every 16 students at primary school level, it has a more generous supply of teachers than the Republic of Korea (1 per 21 students), Cambodia (1 per 48), and Brazil (1 per 22). But the quality of Indonesian teachers is poor: many lack basic competencies, particularly with regards to subject knowledge and pedagogical skills (Jalal et al 2009; Chang et al 2014; Pisani 2013). The World Bank study, for instance, found that 'many teachers have major difficulties with even the most basic mathematical problems' (World Bank 2015: 47). At the same time, Indonesian teachers are poorly distributed between schools, especially between schools in urban and rural and remote areas, and absenteeism rates, while improving, remain high (USAID Prioritas 2015; McKenzie et al 2014; UNCEN et al 2012; Pisani 2013). As one measure of the scale of the distribution problems, USAID (2015) found that teacher-student ratios in 23 districts ranged from 10 in urban Madiun, Central Java, to 25 in the remote rural district of Nias Selatan. Finally, rising teacher salary costs, driven by big increases in teacher pay, have crowded out spending in other areas of the education budget needed to improve education quality. 6

The Indonesian central government has introduced a range of reform initiatives to address these issues since the mid-2000s, some of which are beginning to have positive effects, particularly with regards to teacher numbers and cost and the quality of newly recruited teachers. These have included a moratorium on civil service teacher appointments, a more transparent and accountable system for recruiting civil servant teachers, a teacher certification program, restrictions on the number of terms that school principals can serve, and the issuance of an instruction to regional governments to address teacher distribution problems. But much analysis

\footnotetext{
3 The amendment was made in 2002.

${ }^{4}$ We use the terms 'regional' and 'local' interchangeably throughout this report. In both cases, they are used to refer to districts (kabupaten) or municipalities (kota) and, depending on the context, provinces as well.

${ }^{5}$ Figures are from the World Bank's World Development Indicators database.

${ }^{6}$ For an analysis of the budgetary impact of teacher salary increases, especially ones stemming from the certification program, see Chang et al (2014: 161-162).
} 
suggests that Indonesian teachers nevertheless remain too numerous, too costly, too poor in quality, too badly distributed, and too frequently absent from work (see World Bank 2010a; Pisani 2013; McKenzie et al 2014; Chang et al 2014; Al-Samarrai et al 2012).

This paper examines the role of political economy factors in contributing to Indonesia's current teacher management problems and shaping efforts to resolve them. It suggests that these problems have their origins in the way in which political and bureaucratic elites, at both the national and local levels, have for decades used the school system-and teacher management in particular-to accumulate resources, distribute patronage, mobilize political support, and exercise political control. This orientation has meant that teacher numbers, quality, and distribution have been managed to maximize flows of rents and votes from schools to this elite, lubricate patronage and political networks, and ensure that these elites maintain political control rather than to maximize educational performance and equity. Democratization and decentralization since the fall of the New Order, the authoritarian and centralized regime that ruled Indonesia from 1965 to 1998, have done little to change this situation. They have consolidated the formal authority of regional governments in relation to teacher management and created genuine competition within the local elite for teachers' votes. But schools' role as a source of rents and votes as well as a mechanism for distributing patronage and exercising political control has remained more or less unchanged.

In this context, recent central government efforts to reduce teacher numbers, promote better teacher distribution, and enhance teacher quality through, for instance, more transparent recruitment practices and teacher redistribution have represented a direct assault on elite interests. In particular, given that local elites play the dominant role in teacher management, the central government's efforts have represented an assault on the interests of local elites. Central government reform initiatives have consequently encountered considerable-if often subterranean-resistance except in a few exceptional cases where specific conditions conducive to reform have emerged.

The paper argues - on the basis of an analysis of the political dynamics surrounding specific reforms in a set of regional cases-that these conditions are:

i) where the central government has had at its disposal or been able to devise policy instruments that are effective in disciplining local governments and it has maintained a commitment to these instruments in the face of opposition;

ii) where local civil society groups are present and able to launch effective public campaigns demanding reform, exploiting their ability to access the independent media and, if necessary, the courts; and local governments are able to find effective ways of buying off the losers from reform;

iii) where mid-level government officials, especially ones at the local education agency, have judged that reform initiatives can be exploited for patronage purposes; secured support from above; and officials have devised effective strategies for managing the politics of reform;

iv) where reform-minded district leaders have been elected providing an imperative for education agency officials to design reform programs and the latter have had access to relevant ideas and policy advice as a result of contact with donors; and v) where teachers and the patronage and political networks of which they are part have stood to lose little from reform in the first place. 
In presenting this argument, the paper begins by outlining a conceptual framework for understanding teacher management policy and its implementation in Indonesia (Section 2). It then identifies the contending forces that have been involved in struggles over teacher management in Indonesia (Section 3) and provides a general overview of the way in which struggles between them have played out over time (Section 4). It then examines the political and social dynamics surrounding a range of specific teacher management issues over which contestation has occurred in the post New Order period (Section 5). The final section (Section 6) presents the paper's conclusions, focusing on the policy implications of the analysis for proponents of reform.

\section{Analytical and Methodological Matters}

\subsection{Understanding Teacher Management in Indonesia}

Much work on teacher management policy and its implementation in developing countries has focused on three analytical tasks. The first has been to define and describe teacher management problems in these countries. In this respect, it has been concerned with questions such as the adequacy of teacher supply, utilization, and distribution; the adequacy of teachers' skills and capabilities; the quality of in-service and pre-service teacher training; the effectiveness of systems for teacher recruitment, evaluation and management; and the adequacy of teacher pay. The second analytical task has been to prescribe technical policy solutions to these problems taking into account existing levels of development and budget constraints. The third analytical task has been to assess the effectiveness of proposed solutions through evaluations of the impact of projects and programs and consider the implications for project/program design. The central problematic of this work has been how to maximize educational benefit (as measured, for instance, by national performance in PISA and similar examinations) within the context of a given resource envelope, understood in terms of both government budget finances and human resources. Mulkeen's (2010) detailed analysis of teacher supply, training and management issues in Anglophone Africa constitutes one key contribution in this vein. Others include Gaynor's (1998) analysis of teacher management decentralization in developing countries and various recent reports on teacher management issues in the Indonesian context (see, for instance, Jalal et al 2009; World Bank 2010a; 2010b; Chang et al 2014; World Bank 2015).

This work has served to define a reform agenda in relation to teacher management consisting of measures to increase/decrease the number of teachers (depending on whether countries are considered to be in shortage/deficit); distribute teachers more efficiently throughout the school system; enhance the quality of teacher training; make teacher recruitment, evaluation processes more meritocratic; and ensure that teacher pay is sufficient to attract good candidates into the profession without being excessive. But because this work has focused largely on technical issues, it has not, in most cases, examined the political dynamics surrounding processes of teacher management reform even though some authors have acknowledged that such processes are inherently political in nature (see, for instance, Gaynor 1998). To the extent that they have explored the political dimensions of change, they have tended to see things in terms of individual teacher incentives and behavior. The challenge, it is presumed, is to ensure that teacher incentives align with broader goals such as improved education outcomes and fiscal sustainability. The way in which teacher management issues are embroiled in contestation between larger political and social groups is set aside in favor of making a case for a more 
efficient and effective allocation of resources and designing policy and institutional frameworks that establish the 'right' incentives for actors understood in individual terms. ${ }^{7}$

In contrast, this paper proposes that teacher management policy-making and implementation be understood as an inherently political process characterized by contestation between competing political and social groups over access to and control over resources and power. The key point here is that teacher management reform has redistributive dimensions: it shifts resources and power away from some political and social groups and towards others. In particular, it shifts resources and power away from political and bureaucratic elites, the patronage and political networks they control, and teachers and towards parents of schoolchildren, especially ones in poor areas that have under-resourced and poor quality schools. To the extent that budget savings are achieved through a more efficient allocation of teacher supply, it also shifts resources away from teacher salaries to other areas of public spending (including other areas of education spending) and the interests that are embedded in those areas of spending. For these reasons, teacher management reform is subject to political contestation between groups who stand to benefit from such reform and those who stand to lose from it.

To operationalize this conceptualization of teacher management reform, we draw on an analytical framework that shares much with those developed by Grindle (2004; 2007) in her work on the political economy of education reform in Latin America and Hudson and Leftwich (2014) in their work for the Developmental Leadership Program (DLP). As an academic field, political economy - like many other academic fields - has been characterized by significant debate over the merits of different analytical approaches. Much of this debate has centered on whether analytical primacy should be given to interest-related, institutional or agential factors in explaining political, economic, and/or social change (Rodan et al 2006; Hameiri 2007; Leftwich 2010; Hudson and Leftwich 2014). Our framework seeks to integrate these factors in recognition that they all have at least some bearing on change, albeit in different ways in different contexts. At the same time, it also seeks to interpret and apply these factors in a manner that is sensitive to the historical, political and social specificities of the Indonesian context.

The framework centers on three levels of analysis:

- Level 1: Actors, Interests, and Agendas: This level focuses on identifying the key political actors who are involved in teacher management policy-making and its implementation and their respective interests, policy agendas, and forms of leverage over policy and implementation. Such actors may be specific individuals (such as a local chief executive) but more commonly are groups of individuals or organizations. The latter may include technocratic elites, political and bureaucratic elites, teachers, teacher trade unions, non-government organizations (NGOs), and parent groups.

- Level 2: Institutions: This level of analysis is primarily concerned with understanding the way in which formal and informal 'rules of the game' such as written laws and regulations, cultural values, voluntary codes and standards, and the like structure interactions between political actors. There is accordingly a strong emphasis on questions related to the institutional design of legal and political systems, the nature of laws and government regulations, bureaucratic structures, and the way in which these

\footnotetext{
7 Scholars who have explored the political economy of teacher management reform in developing countries include Kingdon and Muzammil (2009) and Beteille (2009).
} 
shape who has access to decision-making processes, citizens' ability to organize and mobilize for collective action, and the responsiveness of political elites to their interests and concerns. For our purposes, key issues include: What types of political regime have shaped political activity and, in particular, teachers' and education activists' ability to mobilize for collective action? What are the respective responsibilities and powers of central and regional governments with regards to teacher management policy-making and implementation? What is the nature of financial arrangements between different levels of government? What different types of teachers exist under Indonesian law and regulation? How have these changed over time?

- Level 3: Agency: This level of analysis focuses on understanding the role of strategic choice and action, as exercised by individual and organizational actors, in policymaking and its implementation. In particular, it is concerned with these actors' choices and actions with regards to, depending on their respective agendas, the promotion of or opposition to teacher management reform.

In interpreting this framework and applying it to the Indonesian context, we also draw on concepts, language and findings that have emerged from the literature on Indonesia's political economy during the post-New Order period (including previous work by the authors), particularly that focused on politics at the sub-national level. Broadly speaking, this literature has entailed three broad types of study each of which has focused on one or other of the three levels of analysis above.

1. The first type of study has focused on the first level of analysis above and emphasized the political constraints to liberal and progressive reform stemming from continuities in the structure of power and interest between the New Order and post-New Order periods. It has argued that the state remains controlled by the same political, bureaucratic and corporate interests that dominated the New Order while popular forces and NGOs remain weak (Robison and Hadiz 2004). At both the national and local level, it has suggested, this has meant continued rule by figures from military, bureaucracy, business, and, in some cases, preman (street thug) backgrounds. Cabinet ministers, parliamentary figures, provincial governors and district heads appointed by Suharto may have been cleared away following reformasi but they have simply been replaced, in many cases, by individuals occupying the next tier down. Books by Robison and Hadiz (2004), Winters (2010) and Hadiz (2010) have been the most influential exemplars of this type of analysis (see also Hadiz 2003).

2. The second type of study has focused on institutional variables and, in particular, the effects of institutional changes brought about by democratization and decentralization. It has shown that these changes have affected the respective roles of the central and regional governments in the policy-making process and, within the latter, of local parliaments and local executives, producing a shift in policy-making authority away from the central government towards regional (especially district) governments and away from local executives towards local parliaments (Turner and Podger 2003; Ray and Goodpaster 2003). At the same time, however, this work has suggested that the extent of change in both respects has been less dramatic than some proponents of democratic decentralization in Indonesia desired. While local parliaments are meant to issue local regulations jointly with bupatis (district heads), in practice the latter have initiated the vast majority of these regulations and dominated deliberations over their formulation, suggesting that local executives continue to exercise greater authority over 
the policy-making process than local parliaments despite democratization. At the same time, subsequent legal changes have made it harder for local parliaments to impeach bupatis, given bupatis the authority to intervene in the work of local parliaments in certain ways, and strengthened the hand of bupatis in budget preparation and management (Buehler 2009: 278-279). The introduction of direct elections for bupati positions in 2004 - prior to this time, bupatis were elected by members of the district DPRD — has further enhanced their authority vis-à-vis local parliaments by giving them an independent mandate to govern (Schiller 2009: 151-152).

3. The third type of study has taken issue with the broad-brush nature of the first and second types of study, pointing out that district-level governments have varied in their responses to a range of policy issues. For instance, while many district governments have done little to improve access to or the quality of public services, some have been quite progressive, investing heavily in programs of free education and health care. This third type of study has accepted that there has been considerable continuity in the structure of power and interest in Indonesia. But it has argued that some scope for reform has emerged as a result of democratization because local politicians now have an electoral incentive to adopt popular policies or NGO activists have had greater freedom to push for change (Rosser and Wilson 2012; Rosser and Sulistiyanto 2013; Aspinall 2014; Rosser 2015). In terms of the framework above, it has emphasized the third level of analysis.

The three different levels of analysis - and the concepts, language and findings from the literature on Indonesia's political economy that inform our understanding of them-permeate all sections of this paper. However, Section 3 focuses on the first level of analysis while section 4 illustrates how changes in the institutional arrangements that characterized the New Order and post-New Order periods-specifically with regards to the nature of the country's political regime and the division of responsibilities between the central and regional governmentshave served to shape these struggles. The role of agency then enters the analysis more substantively in Section 5 on the politics surrounding specific teacher management reforms as we look at the strategies pursued by different sets of actors - including bupati and NGOs-in pursuit of their respective agendas. Before we enter into this analysis, however, it is necessary to note a few points about the methodological approach employed in the study.

\subsection{Notes on Methodology}

\subsubsection{Sources of Data}

The analysis presented in this paper is based on material from primary and secondary sources, much of which was collected during fieldwork in Indonesia between May and August 2015, although we have also drawn to a limited extent on material collected before and after this time. Primary material was collected through interviews with national and regional government officials, donor officials, civil society activists, political party/parliamentary representatives, journalists, parent groups, teacher organizations, school principals and teachers in Jakarta and four districts/municipalities in two provinces. We also carried out one interview in a fifth district with the head of the local education agency and some of her staff. In total, we conducted 92 interviews across Jakarta and these districts/municipalities. To ensure confidentiality we have anonymized the names of districts/municipalities - we refer to them as District A, District B, Municipality A, and Municipality B, respectively_as well as our interviewees throughout 
the paper. We have also avoided references to names of individuals and documents that could identify the districts and/or interviewees. A reliance on interview data poses some methodological problems particularly with regards to the accuracy of the data collected (informants may not remember events correctly, interviewers may misinterpret their comments) and the potential for bias (informants may present only one side of a story). Accordingly, where possible, we have sought to double check information collected through interviews with other interviewees or secondary sources and to secure the views of a range of stakeholders. Secondary material was collected through online newspaper and media outlets, government publications, donor reports, and previous academic studies. We also examined, where relevant, laws and regulations provided to us by informants or that we were able to source online.

\subsubsection{National vs. Regional Focus}

The focus of the paper is on the regional level given that, under Indonesia's current decentralized system of government, primary responsibility for managing teacher management issues lies at this level. However, in examining this topic, the paper gives significant attention to the role of the central government and national level politics in shaping outcomes at the regional level. As Section 5 illustrates, the central government has played a crucial role in setting the incentives that regional governments face vis-à-vis teacher management and the scope that they have to effectively resist reform through its use of central policy instruments. In some cases, it has designed effective policy instruments for promoting teacher management reform and remained committed to them in the face of political resistance. In other cases, it has either failed to devise such policy instruments in the first place or watered them down in the face of resistance. Whether the central government has played a disciplining role or effectively left regional governments to their own devices has thus been a crucial determinant of outcomes at the regional level, making it an important matter for the study.

\subsubsection{Comparative Orientation}

The paper is focused solely on Indonesia's experience with teacher management policy and implementation. However, it incorporates a comparative element by seeking to explain differences in policy and implementation outcomes across different types of teacher management reform. Work in comparative political economy has been primarily concerned with cross-national comparisons. But in recent times, it has embraced 'within-case comparison', a study design that entails comparison of outcomes across time, region or issue within particular national contexts.

This study employs such a study design. The four districts chosen as the focus for fieldwork all have a clear need for reform in teacher management as indicated by their teacher-student ratios and indicators related to the distribution of teachers (see Annex One). It is reasonable to assume that they also all face problems related to teacher competencies. However, each district-level government has responded differently to the need for reform. All have introduced one or more types of teacher management reform but the nature of these reforms and the extent to which they have been implemented has varied significantly from case to case. District B has introduced measures such as teacher redistribution but done little in relation to most other areas of reform. District A has also carried out teacher redistribution but done little in other areas of reform. Municipality A has sought to regroup schools and carry out periodization of school 
principals but not yet conducted teacher redistribution. Municipality B has been relatively slow off the mark in relation to all aspects of teacher management reform but is beginning to carry out teacher redistribution and periodization. In short, these four regions provide a rich tapestry of material for exploring the political dynamics surrounding specific reforms and understanding why they have proceeded in some cases but not others.

\section{The Contending Forces}

Struggles over teacher management policy and its implementation in Indonesia have involved several sets of actors, each of which has had distinct interests, policy agendas and ways of exercising leverage over policy-making and implementation. These actors include technocratic elites, political and bureaucratic elites, and, of course, teachers and their unions.

\subsection{Technocratic Elites}

Technocratic elites are government officials with a high level of academic trainingparticularly in economics but also, in some cases, other fields-who have the capacity to analyze statistical data and make decisions on the basis of economic or scientific principles. Many have received their training from leading foreign universities, particularly in Europe and the United States and, to a lesser, extent Australia. Their principal concern with regards to education policy for several decades has been to promote improved access to education-in particular basic education but in more recent years secondary education as well-through expansion of the school system and the introduction of policies of free and/or universal education (see, for instance, Prawiro 1998: 176-181). But they have also given attention to issues of teacher quality, teacher redistribution, and teacher numbers and cost. In seeking to achieve these goals, one of their key concerns has been to ensure that government spending on education - and in particular teachers' salaries —is used as efficiently as possible and does not impose an excessive burden on the budget (Jalal and Mustafa 2001; Jalal et al 2009). Technocratic actors have not been immune to rent-seeking behavior given that they are embedded in patronage networks like other officials. But, at the policy level, they have generally advocated measures to improve governance of the education system.

Technocratic officials have historically been located in a range of central government ministries and agencies but, in particular, the National Ministry (previously Agency) for Development Planning (Bappenas), the Coordinating Ministry for Economic Affairs, and the Ministry of Finance (Jawa Pos 2014; Balikpapanpos 2014). The Ministry of Education and Culture (MoEC) has also had a significant cohort of technocratic officials although generally with academic training in fields other than economics. During the second term of the Yudhoyono government (2009-2014), a crucial period as far as this study is concerned, Vice-President Boediono, a foreign trained economics professor, emerged as a key technocratic actor in addressing these issues. This was primarily due to his role as Chair of the Education Committee, a cabinet sub-committee bringing together representatives from, among other ministries, the Ministries of Education and Culture, Finance, State Administration and Bureaucratic Reform, Internal Affairs, and Religious Affairs (Kompas 2010; Vice President of Indonesia 2011).

Technocratic elites have lacked a significant domestic support base that is capable of mobilizing politically to promote their policies or capturing the state apparatus through the electoral process. But they have risen to senior positions within government, gained control over 
government programs and budgets, and exercised leverage over government policy because of structural pressures on the government-specifically, the need for the country to enhance human resources in a cost-effective way in order to maintain national economic competitiveness while ensuring fiscal sustainability. They have also attracted support from the foreign donor community, enabling the government to access the resources that donors control. Among donors, the key proponents of teacher management reform have been the World Bank, the US Agency for International Development (USAID), and Australia's Department of Foreign Affairs and Trade (DFAT), all of which have been extensively engaged in Indonesia's education sector and teacher management issues in particular. In addition to funding a series of projects focused on these issues (see below), donors have also carried out extensive related analytical work (see, for instance, World Bank 2010a; 2010b; Al Samarrai et al 2012; and USAID Prioritas 2014; 2015). Finally, technocratic elites have drawn some support from the Indonesian business community, at least to the modest extent that the latter has sought to promote change in the country's approach to teacher management (see below).

\subsection{Political and Bureaucratic Elites}

Political and bureaucratic elites, as that term is used here, refers to state officials occupying senior positions in the executive, legislative and judicial arms of government who-in contrast to technocratic elites-have been driven primarily by rent-seeking and political agendas rather than a desire to promote reform. Such officials have long permeated the state apparatus at both the national and local levels (Robison and Hadiz 2004). Importantly for our purposes, they have also permeated those parts of the bureaucracy responsible for teacher management. A series of recent corruption cases related to government procurement in the education sector at the national and local levels has exposed the identities and modus operandi of some figures within this group. ${ }^{8}$ But, in general, these figures can be difficult to identify because networks of corruption and patronage operate in the shadows that sit behind formal institutions, making it difficult to see clearly how they operate and whom they embrace. While government procurement of school supplies, textbooks, equipment and construction has been the most obvious source of rents for these elites (Box One), they have also had important interests at stake in relation to teacher management.

\section{Box One Special Allocation Funds}

Since the implementation of decentralization in 2001, the central government has provided Special Allocation Funds (DAK) to regional governments to finance central government initiatives that are implemented by the regions. Among these initiatives are activities related to school building, construction and repair. Funds for these activities have been a source of rents for political and bureaucratic elites at the local level. In interviews with various informants, it became clear that much rent-seeking in relation to these funds occurred via the agency of NGOs with close connections to senior political and bureaucratic figures. Often referred to as LSM plat merah (literally, 'red license plate NGOs', a reference to the fact that government cars have red license plates), these NGOs typically extort money from school principals and local education agency officials by threatening to make public allegations of corruption and impropriety in relation to the use of DAK funds unless they hand over a share of the funds. This

\footnotetext{
${ }^{8}$ See, for instance, Amelia (2012) and Setuningsih (2012).
} 
money is then presumably channeled upward to senior political and bureaucratic figures. Such NGOs are often staffed by thugs or members of criminal gangs known as preman.

Firstly, teacher management has represented a way in which political and bureaucratic elites, at both the national and local levels, have enriched themselves and their allies or mobilized resources for favored institutions and pet projects. Central government officials have had control over the number and type of teacher positions, enabling them to do deals with regional governments over how these positions are allocated between regions. Likewise, regional government officials have had control over teacher appointments, enabling them to sell teacher and school principal positions to the highest bidder or, alternatively, appoint friends, family members and political allies to such positions. ${ }^{9}$ Either way, they have gained control over school-level rent-seeking opportunities. Most crucial in this respect have been school principal positions because of their responsibility for school budgets (Widoyoko 2005). In general, socalled sekolah favorit (literally 'favorite' schools-i.e. schools where there is high demand for student places) have presented greater rent-seeking opportunities than non-favorite schools because of the fact that they have attracted students from more affluent backgrounds than other public schools and have, consequently, had greater potential to extract resources, legitimately or otherwise, from parents. Teacher management has also provided an opportunity for political and bureaucratic elites to generate funds for elite-dominated institutions and prestige projects through levies on teachers' salaries, the latter being the largest single item of expenditure in the education budget (see Box Two).

\section{Box Two \\ Levies on Teachers' Salaries}

Example A

According to media reports, in 2003-2004, the head of District A's education agency and head of the agency's finance section were prosecuted for misuse of infak funds intended to finance the renovation of the local Grand Mosque (Masjid Agung) as well as funds related to the Broad Basic Education program. The infak funds, which are formally voluntary contributions or a form of charitable payment, had been mobilized through non-voluntary deductions from teachers’ salaries, provoking complaints from over 1,000 teachers across the district.

\section{Example B}

In interviews, several informants told us that it is not uncommon for certified teachers to share their respective professional allowances - an additional payment that such teachers receivewith guru honor at the same school. This redistribution would appear to be instigated by the school principal. While this practice can be seen as consistent with Indonesian cultural norms of 'shared poverty' it is also consistent with the logic of patron-client networks to the extent that guru honor-typically appointed by school principals-may be the latter's relatives or friends.

Secondly, by cultivating patronage networks through teacher management decisions, political and bureaucratic elites at the national and local levels have also been able to build political networks, mobilize votes during elections and exercise political control. The recruitment of additional teachers, increases in their pay, and offers of promotion or transfer to more lucrative roles has been a way for incumbent or aspiring politicians to secure political support within the school system. As leading figures within local communities, teachers have been able to exercise

${ }^{9}$ On this practice, see Kompas (2002). 
some influence over how people in their communities vote at election time, making their support a potentially valuable asset. As the individuals responsible for delivering curricula related to Pancasila (the state ideology) and more recently citizenship and behavior, they have also played a crucial role in ensuring Indonesian students and their families remain loyal to the state.

Political and bureaucratic elites have accordingly sought to manage teacher numbers, quality, and distribution so as to maximize the rents and votes that flow from schools upward through the bureaucracy or directly to elites and these elites' political control over the populace. This orientation has entailed: i) maximization of the number of civil service teacher positions funded by the central government-regardless of whether there is a bona fide need for extra teachersso as to maximize patronage resources at their disposal; ii) use of local government resources to employ additional honorary teachers, particularly in the run-up to local elections, again regardless of whether there is a bona fide need for extra teachers (Pierskalla and Sacks 2015); iii) efforts to ensure the appointment of friends, family members and political allies to teacherespecially school principal—positions rather than the best qualified candidates; iv) support for the charging of illegal fees by schools and misuse of school and local education budgets; v) extraction of legal and illegal fees from teachers' pay without threatening their continued political compliance; and vi) use of promotions, demotions and transfers to reward or discipline teachers for providing/not providing political support (see Box Three). To the extent that such practices have worked against educational quality and equity and fiscal prudence, they have been at odds with the technocratic agenda.

\section{Box Three \\ Teacher Politicization \\ (Politisasi Guru)}

It is not uncommon for teachers who back losing candidates in elections for regional head (i.e. bupati/mayor) to be 'punished' by being moved to isolated parts of a region. According to Ilfiyah et al (2015: 28):

Teachers who oppose their superiors such as school principals, local education agency sub-district branches, heads of local education agencies, or even regional heads will be shifted to isolated schools. This even happens in the periods leading up to and after elections for regional head. Teachers who are considered to be politically opposed to regional heads will be shifted to isolated schools far away from their families. Or teachers who support losing candidates in elections for regional head must be prepared to be shifted from their schools.

In one case, we heard that a school principal had been di-nonjob-kan (shifted to position where he had nothing to do and no resources at his disposal) after publicly aligning himself with one of the mayor's rivals at the forthcoming mayoral election. After the rival candidate won the election, he was then promoted to head of the education agency. ${ }^{10}$

In pursuing their interests, political and bureaucratic elites have been able to take advantage of the fact that they have occupied the state apparatus and, in particular, those parts responsible for teacher management policy and its implementation. These have included the Ministry for the Empowerment of the State Apparatus (MenPAN) and various regional government bodies such as education agencies (Dinas Pendidikan), civil service agencies (BKD), and Advisory Boards for Position and Rank (Baperjakat). MenPAN has had responsibility for determining the number and type of new guru PNS positions awarded to regions, making it possible for its

${ }^{10}$ Interview with a university academic and member of the local Education Board. 
officials to sell civil service positions to regional elites looking for additional patronage resources. ${ }^{11}$ Regional government bodies have in turn been responsible for hiring and promotion decisions. School principal promotions, for instance, have been tightly controlled by senior local government officials through Baperjakat, a body that typically comprises the Regional Secretary (Sekda) (the head of the local civil service), several of his/her assistants, the Inspector, and the head of the BKD. The head of the local education agency generally does not sit formally on this board but is able to make recommendations to it. The Regional Secretary and education agency head also play an important role in making decisions about the rotation of public school principals through their positions on another body, the Final Assessment Team (Tim Penilaian Akhir).

\subsection{Teachers}

Indonesian teachers fall into two broad groups:

- $\quad$ Civil servant teachers (guru PNS): These teachers hold permanent positions and receive relatively good salaries and pension benefits compared to many other Indonesian workers and in particular honorary teachers (on the latter, see below). They are virtually un-sackable. The vast majority are found in public schools. In the past, some civil servant teachers were assigned to private schools but this has become increasingly rare: a 2010 national regulation gave permission to regional governments to withdraw guru PNS from private schools (Kompas 2010a) and many regional governments have responded by doing precisely that. Ambitious and successful guru PNS have a clear career path ahead of them that entails promotion to school principal (kepala sekolah), supervisor (pengawas), and then bureaucratic positions in the local education agency (dinas pendidikan), all the while retaining civil servant status. Those who make it through to head of the local education agency are then well-placed to run for district head or mayor. Teacher management reform has presented a threat to these teachers to the extent that it has entailed possible reduction in teacher numbers, relocation to less desirable/more remote schools, increased workloads, fewer promotion opportunities, greater accountability with regards to teaching quality, and reductions in salary and conditions. Where rewards have been offered to teachers who are subject to reform initiatives - for instance, access to new allowances - their incentives can be different. But in the absence of such rewards, teacher management reform has essentially been a threat to them.

- Honorary teachers (guru honor/honorer): These teachers are casually employed and do not have civil servant status. Most are employed directly by schools using School Operational Assistance (BOS) funds but some are employed by regional governments (the latter being referred at as guru honor daerah or guru honda). The term guru honor is often used to refer specifically to casually-employed teachers who work at public schools. But in District A and Municipality A, we noted that it was used by honorary teacher organizations to encompass both casually-employed teachers in public schools and all teachers in private schools. ${ }^{12}$ The common denominator between these two sets of teachers is a relative lack of job security, lower salaries and lower pension benefits

\footnotetext{
${ }^{11}$ Interview with anti-corruption activist, Jakarta, May 2015.

${ }^{12}$ In interview, figures from a local organization representing guru honor in District A argued that there are no permanent private school teachers (guru tetap yayasan) in the district. All are employed on a casual basis. District A, June 2015.
} 
compared to guru PNS. There is no consistency in the amounts that guru honor are paid or the basis on which they paid with some being paid by the hour, others by the day, and other again a flat rate per month regardless of hours worked. ${ }^{13}$ In contrast to guru $P N S$, honorary teachers have no clear career path ahead of them: without civil servant status, they cannot be promoted to school principal or supervisory positions, or administrative positions in the local education agency. While teacher management reform has generally entailed initiatives related to guru PNS, it has also presented a threat to honorary teachers to the extent that it has potentially reduced their opportunities for work and/or the scope for them to upgrade from honorary to civil servant status. This, as we will see, has particularly been the case with controls on the appointment of new guru PNS, teacher redistribution, school mergers and multi-grade teaching.

In contesting teacher management policy and its implementation, teachers have been severely constrained by their structurally subordinate position vis-à-vis technocratic elites and political and bureaucratic elites-specifically, the fact that (except for those promoted through to positions in the local education agency) they do not occupy positions of authority in the state apparatus. During the New Order period, teachers were also constrained by authoritarian controls on civil society activism and independent organization. During the freer political climate of the post-New Order period, however, they have had a number of avenues of protest available to them. These have included being able to engage in public debate over policy issues and organize for collective action through teacher trade unions. Claiming a membership of 1.9 million teachers (roughly two-thirds of the total),${ }^{14}$ the Indonesian Teachers Union (PGRI) has been the most important vehicle in this respect. But newer independent unions such as the Indonesian Independent Teachers' Forum (FGII), the Independent Teachers Action Forum (FAGI), the Indonesian Teachers Union Federation (FSGI), and the various organizations representing guru honor have also been very active in recent years, particularly at the national level, although their memberships are doubtless vastly smaller than the PGRI. ${ }^{15}$ Other avenues of protest have included exploiting teachers' personal social and political networks to directly lobby local political and bureaucratic elites in relation to specific teacher transfer, promotion or other decisions; and challenging such decisions in court.

\subsection{Other Actors}

Three other sets of actors have also played a role in struggles over teacher management policy and its implementation during the post-New Order period, albeit relatively minor roles. The first of these has been activists associated with ICW's Public Service Monitoring Division. Since its establishment in the late 1990s, ICW has been a trenchant critic of the central government's education policies, particularly those seen to promote the 'privatization' or 'commercialization' of education. It played a leading role in defeating government policies on international standard schools and educational legal entities through legal challenges at the Constitutional Court (Rosser and Curnow 2014; Rosser 2015). With regards to teacher management reform, it has been less vocal and more sympathetic to central government policy. To the extent that ICW activists have commented on teacher management reform, they have i) acknowledged the need for improvement in teacher quality and distribution although not

\footnotetext{
${ }^{13}$ Interviews with various school principals and teachers in District A, Municipality B and District B, June-August 2015. See also Padmawati (2010: 20).

${ }^{14}$ See http://download.ei-ie.org/Docs/WebDepot/PGRI_Presentation_DCmeeting.ppt.

${ }^{15}$ According to one recent media report, FSGI, for instance, has 3,000 members (Mustakim 2015).
} 
necessarily reductions in teacher numbers; and ii) lambasted the government for failing to implement its policies in this area (rather than for the nature of these policies). For instance, in a 2015 USAID-funded report, Ilfiyah et al (2015) noted the desperate need for better teacher distribution and lamented the fact that the central government had made relatively little progress in effecting change. To the extent that ICW activists have engaged in debates over teacher management reform, therefore, their position has been, in important respects, broadly supportive of government policy and consistent with the technocratic agenda-in marked contrast to their stand on many other education policy issues (Rosser and Curnow 2014). This stance has removed a key source of potential opposition to teacher management reform.

The second set of actors has been parents of school children (hereafter just parents). Parents in Indonesia are poorly organized. Few parent representative groups exist and those that do have typically been formed to influence decision-making within particular schools in affluent areas. They have consequently been concerned with the particular problems of school management in so-called sekolah favorit (which tend to be located in these areas) rather than schools in general. Other mechanisms of potential parental influence have included school committees (komite sekolah) and district-level Education Boards (Dewan Pendidikan). But the former have generally been dominated by school principals while the latter have generally been dominated by local political and bureaucratic elites and/or parents from middle class backgrounds. Both are typically poorly funded and sometimes inactive. Combined together, these factors have limited the scope for genuine involvement of parents in decision-making, particularly poor parents and, along with limited NGO activity, severely constrained citizen demand for change at both the national and local levels. Parents have also played a role in relation to teacher management issues - albeit in a way that has not aided reform-to the extent that they have constituted a resource upon which individual teachers have drawn in seeking to influence transfer and promotion decisions.

The third set of actors has been Indonesian business groups and their main representative organizations, the Indonesian Chamber of Commerce (KADIN) and the Indonesian Employers' Association (APINDO). Indonesian businesses have long complained of difficulty in recruiting skilled workers, especially to fill management positions. But, neither they nor their representative organizations have lobbied strongly for the government to improve access to and the quality of the country's education system-in particular by improving teacher management-perhaps fearing that it would open up the possibly of increased corporate taxation. ${ }^{16}$ Also, for many business groups, the issue of improving education quality has been a minor concern because the key to business success has been gaining access to government contracts, grants and licenses rather than building competitive advantage through technological development. This has particularly been the case at the local level. As a result, as Guharoy (2008) has noted, Indonesian businesses and their representative organizations have tended to be 'silent' on education issues, focusing their lobbying efforts instead on trying to promote more flexible labor regulations and secure various forms of government largesse. A recent report by APINDO (2014), for instance, calls for government subsidization of business inhouse training programs as the main way of addressing skill shortages.

In 2012, McKinsey and Co (2012) issued a report on the Indonesian economy that shifted the focus by calling for a range of measures to improve the quality of Indonesia's education system.

16 Tendler (2002) has suggested that for businesses in developing countries, employers requiring unskilled labor can 'fear' education as it will reduce the pool of potential employees willing to work as unskilled labor, lead to out migration and reduce their comparative advantage by pushing up wages. It is difficult to know to what extent this factor has been at work in the Indonesian case. 
Specifically, it called for the government to raise 'the standard of teaching with an emphasis on attracting and developing great teachers' (2012: 8). To this end, it proposed that the government should increase teacher remuneration, recruit teachers from the top tier of graduates, and improve teacher distribution. This report may signal a change in the business community's approach to education issues. But such pronouncements still remain the exception rather than the rule.

In the following sections, we illustrate how struggles between these various actors have played out during the post-New Order period. In so doing, we begin by examining the politics of teacher management under the New Order, noting the way in which the balance of power between political and bureaucratic elites, technocratic elites and other actors and the nature of New Order's political institutions shaped the number, employment, distribution and quality of teachers during that period. We then examine how the collapse of the New Order and the broader political and institutional changes it produced has changed the politics of teacher management in Indonesia. In this respect, we begin by examining the politics of teacher management in post-New Order Indonesia in general terms before examining the politics of various specific teacher management issues.

\section{The Political Economy of Teacher Management: Overview}

\subsection{Background: The New Order Period}

Under the New Order, military and bureaucratic officials dominated Indonesian politics along with the business groups to which they were linked. The Indonesian military seized power in a coup in 1965. Thereafter, its leaders emasculated the political parties and the national parliament, gained control over the bureaucracy through the appointment of military officials to senior bureaucratic positions and the introduction of requirements for government bureaucrats to support Golkar, and subordinated the judiciary to political and bureaucratic authority. At the same time, they re-engaged with the donor community and sought to attract mobile private domestic and foreign capital back into the country through the introduction of economic policy reforms. As part of this process, they gave substantial authority over economic and social policy to a group of economic technocrats known collectively as the 'Berkeley Mafia' (Robison, 1986; Winters, 1996). By contrast, the poor and NGO elements were prevented from exercising much influence over policy-making and its implementation by the imposition of authoritarian controls on their activities (Robison and Hadiz, 2004).

With the technocrats exercising significant influence over economic and social policy, the New Order invested heavily in promoting improved access to education, especially basic education, through expansion of the school system. This was particularly the case during the oil boom years of the late 1970s and early 1980s when the government was awash with petrodollars (Prawiro 1998: 176-181). A significant part of this investment was used to recruit new teachers to staff new schools that were built throughout the country, in particular, in regional and remote areas.

Corruption, however, served to undermine the educational effectiveness of this new investment in the school system. Indonesian schools became part of the larger 'franchise' structure that characterized the New Order's rule, the key feature of which was the purchase of government positions in exchange for access to the rents they could generate (McLeod 2000). Local 
community members such as parents, who had previously played a central role in school management, were pushed aside in favor of politico-bureaucratic figures who bought their positions at schools from local education officials in exchange for the opportunity to make money through corruption, fees, and the appointment of friends to teaching positions (Rosser and Joshi 2013; Irawan et al 2004: 50). In this context, teachers became incorporated into networks of corruption and patronage as both generators and beneficiaries of the rents that education budgets and teaching positions made available.

At the same time, schools became vehicles through which the New Order mobilized votes at election time and exercised political control (Schiller 1999: 11; Bjork 2003: 192-193). The school system was one of few national institutional structures that reached all the way down to the village level, making it an extremely important link between political and bureaucratic elites and the masses. As civil servants, teachers were required to support Golkar, the New Order's electoral vehicle; display 'mono-loyalty' to the state; and both take and teach compulsory courses in the state ideology, Pancasila. If they failed to perform these responsibilities, they risked demotion or transfer to less attractive schools, particularly in remote areas. Teachers were also required to be members of the Indonesian Teachers Union (PGRI), the sole recognized teachers' trade union. Established in 1945 as part of the nationalist resistance to Dutch rule, the PGRI operated during the New Order period as a mechanism for controlling teachers rather than the articulation of their collective interests. Its political subordination was made transparent by its incorporation into Golkar in 1970 (Kompas 1970). In exchange for its allegiance to the New Order, it was given a monopoly on the representation of teachers and authority to extract fees from teachers' salaries with little or no accountability over use of the associated funds (Reeve 1985: 328).

In this context, there was little political will within government to address issues related to teacher quality, teacher distribution, or teacher numbers and cost. Rather the dominant logic at work was to expand and consolidate networks of corruption and patronage and enhance political control. This meant maximizing teacher numbers to provide additional patronage opportunities while expecting little of teachers in terms of accountability for educational outcomes. One consequence was a marked growth in teacher numbers. Another was high absenteeism rates as teachers were permitted to sacrifice their teaching responsibilities to pursue income earning opportunities outside of school without simultaneously sacrificing their salaries. A third consequence was a mal-distribution of teachers as political and bureaucratic elites ensured that their friends, family and political allies gained teaching positions at schools in urban areas near their family and social networks. Particularly privileged in this respect were the sekolah favorit that schooled children of local government officials and other members of the middle class.

A final consequence was poor quality teacher training, both pre-service and in-service. Until 1990, students were able to qualify as primary school teachers by graduating from senior vocational secondary schools known as Teacher Education Schools (SPG). According to Jalal et al (2009: 9), these offered low quality training and 'graduates usually did not meet minimum standards of competency.' Tertiary teacher training colleges known as IKIP (subsequently LPTK) were better in quality. But they still faced serious issues such as underqualified faculty, a rigid curriculum, and inadequate facilities (World Bank 1996: 3-4). Indonesian teachers consequently generally had poor pedagogical skills and weak subject knowledge despite efforts from time to time to enable them to upgrade their academic qualifications. 
The negative impact of this situation on the quality, equity and cost of Indonesia's education system soon became apparent (World Bank 1989: 3), forcing the government to look more seriously at teacher management issues. The result was a series of initiatives during the 1980s and 1990s aimed at improving teacher qualifications, pedagogical skills and/or distribution including the First and Second Secondary Education and Management Projects (1984-1990 and 1990-1997 respectively), the Primary School Teacher Development Project (1992-1999) and the Secondary School Teacher Development Project (1996-2002), all of which were funded by the World Bank. In the end, however, these initiatives proved insufficient to fundamentally improve the quality of Indonesia's teachers, improve their distribution, or ensure their numbers matched the country's genuine need for teachers. Without the requisite political will to improve teacher quality and promote a more efficient use of teacher resources, there was little scope for any significant change.

\subsection{The Post-New Order Period}

The Asian economic crisis in 1997 and demise of the New Order regime in 1998 produced a political context that was slightly more conducive to teacher management reform. By precipitating widespread corporate bankruptcy, the crisis undermined the economic base of New Order elites and their corporate clients. By simultaneously increasing the country's public debt and undermining sources of government revenue, it forced the government to negotiate a rescue package with the International Monetary Fund (IMF) and accept increased aid. Both these factors enhanced the structural power of donors, at least for the period of the crisis and its immediate aftermath. While the IMF package did not address education policy issues beyond the introduction of new social safety net programs, it created an environment in which government technocrats and donors were able to exercise much greater leverage over education policy than they had before.

In this context, government technocrats, particularly in Bappenas and MoEC, pushed hard for teacher management reform, leveraging the support of the World Bank and other members of the donor community. In September 1998, the Bank published a major report on Indonesia's education system that argued that: 'A key part of quality improvement is teachers-having them equitably distributed, giving them appropriate incentives, and ensuring they are adequately trained' (World Bank 1998: x). Immediately afterward, it then co-funded with Bappenas the establishment of a series of Task Forces to prepare reports on key education policy issues including teacher management (Jalal and Musthafa 2001). These Task Forces brought together a range of key stakeholders including Bappenas officials, MoNE officials, education academics and representatives of the PGRI. Over the next few years, donors provided loans and grants to the Indonesian government to support a series of projects related to teacher management reform (see Box Four).

\section{Box Four \\ Donor Projects on Teacher Management}

\section{Bermutu}

The Better Education through Reformed Management and Universal Teacher Upgrading (Bermutu) project was supported by the World Bank and the Dutch government (World Bank 2014). The project started on 5 July 2007 and finished on 31 December 2013. The objective of Bermutu was to contribute to the improvement of the overall quality and performance of teachers through enhancing teachers' knowledge of subject matter and pedagogical skills in the 
classroom. The project had 4 main components which did not change until the end. They were (1) reforming university-based teacher education; (2) strengthening structures for teacher improvement at the local level; (3) reforming teacher accountability and incentives systems for performance appraisal and career advancement; and (4) improving program coordination, monitoring and evaluation. The project was implemented in 16 of Indonesia's 34 provinces.

\section{Kinerja}

Kinerja is a USAID initiative that was aimed improving how local governments deliver public services (USAID 2013). It ran from September 2010 until September 2015. It worked through local institutions to build their capacity and encourage sustainable partnerships with local government while building on a body of existing innovative practices in local governance programs and sector initiatives. It involved three main activities: (1) establishing incentives for local governments to improve service delivery, (2) adopting innovative service delivery approaches, and (3) expanding the application of improved practices to other local governments through replication. This focus included measures related to education governance and specifically the distribution of teachers (USAID 2014a). Kinerja was implemented in Provinsi Aceh, Jawa Timur, Kalimantan Barat, Sulawesi Selatan, and Papua.

\section{Prioritas}

Prioritizing Reform Innovation and Opportunities for Reaching Indonesia's Teachers, Administrators and Students) (Prioritas) is a five-year USAID-funded project designed to improve access to quality education for children in Indonesia (USAID 2014b). It began in May 2012 and will be finished by 2017. Prioritas's objectives are to strengthen instruction in schools in targeted districts, improve education management and governance, and strengthen coordination within the education system. To this end, it has concern, among other things, with teacher deployment. It is working in seven provinces that previously partnered with USAID's Decentralized Basic Education (DBE) project: Aceh, Sumatra Utara, Banten, Jawa Barat, Jawa Tengah, Jawa Timur, and Sulawesi Selatan. In April 2014, it started to work in Papua Province, supporting the work of two nongovernmental organizations (NGOs) in the highland areas of the province.

\section{Prodep}

Professional Development for Education Personnel (Prodep) is component 2 of the Australia's Education Partnership (Leslie and Strudwick 2015). It began in July 2014 and will run until July 2016. It has been implemented in 250 districts in 32 provinces (Prodep 2015). The purpose of Prodep is to develop a national system for the professional development of Education Personnel and, in so doing, improve the competence and performance of school principals and madrasah heads, supervisors, and education officials at the district and province level who are responsible for the management and governance of schools or madrasah. Four main professional development programs run by Prodep are: building of education capacity of local government program, candidate principal preparation program, principal mentoring program by supervisors, and principal professional development program.

However, in seeking to promote teacher management reform, government technocrats and their allies in the donor community have been constrained by three factors. The first has been the fact that they have had little direct authority over the implementation of teacher management policy. Under the New Order, regional governments already had primary responsibility for implementing teacher management policy notwithstanding the centralized nature of New Order rule and despite an effort in the early 1990s by the national Department of Education and Culture to seize that responsibility for itself (King 1995: 82-84). The introduction of new 
decentralization laws in 1999 and their implementation in 2001 consolidated the role of regional governments in this respect by granting them formal authority over education policy. Central government technocrats have accordingly been forced to rely, by and large, on central government policy instruments that establish incentives for regional governments to act in ways that accord with the technocratic agenda rather than direct control over implementation. The most significant of these instruments in recent years-as we will see below-have been a moratorium on new civil service appointments in regions that spend more than a certain proportion of their budgets on salaries, a new national teacher certification program aimed at improving teacher subject knowledge and pedagogical skills, and a joint ministerial regulation instructing regional governments to address teacher distribution problems. The central government's lack of direct control over teacher management, however, has severely constrained government technocrats' ability to promote change.

The second constraint has been the continued political dominance during the post-New Order period of military and bureaucratic officials and their corporate clients. As Vedi Hadiz (2003, 593) among others has argued, these elements were 'able to reinvent themselves through new alliances and vehicles' such as political parties with the result that they have maintained instrumental control over the state apparatus notwithstanding the shift to a more democratic political system. The result has been that, at both national and regional levels, long-standing patronage and political networks have remained an entrenched feature of governance.

In the education sector, for instance, senior staff at MoEC and the Ministry of Religious Affairs (MoRA) have continued to be recruited largely from among rectors, deans and lecturers at the public universities under these Ministries' control, particularly those who have civil servant status ${ }^{17}$ and are members of Muhammadiyah or Nahdatul Ulama, the country's largest Islamic organizations, both of which have long been integrated into state-based patronage networks in the education sector. This has included in most cases the Ministers themselves (although the appointment of Anies Baswedan, rector of the private Islamic Paramadina University, as Minister in 2014 represented a break with this pattern). At the same time, positions in local education agencies have continued to be awarded to former guru PNS who have either bought their way into these positions or had close personal connections to more senior officials or members of the political elite; and schools and other local-level educational institutions have remained part of the franchise structure of the state as well as mechanisms for mobilizing votes and exercising political control (see Box Five). In short, political and bureaucratic elites nurtured under the New Order have continued to have enormous capacity to influence education policy and its implementation and, in the process, undermine reform.

\section{Box Five Teacher Deliberative and Working Groups}

In theory, all Indonesian civil servant teachers should participate in local deliberative or working groups that run activities aimed at enhancing teacher professionalism and quality. Many guru honor - for instance, those working as primary school class teachers (guru kelas) are meant to participate in these groups as well. For primary school teachers, the groups are known as Primary School Teacher Working Groups (KKGSD) while for junior secondary and senior secondary teachers, they are known as Subject Teachers Deliberative Groups (MGMP). Among the former, there are groups representing teachers for each year level-i.e. KKGSD

\footnotetext{
${ }^{17}$ Like principals and teachers in public schools, university managers and lecturers in public universities often have civil servant status.
} 
Grade One, KKGSD Grade Two and so on. Among the latter, there are separate MGMP for junior and secondary schools and for each subject on the curriculum-i.e. there are groups called, for instance, MGMP SMP Maths, MGMP SMA Maths, MGMP SMP English, MGMP SMA English. School principals have their own deliberative or working groups known as School Principal Working Deliberative Groups (MKKS) which, again, are divided by school level-i.e. there are separate groups for MKKS Primary, MKKS Junior Secondary, and MKKS Senior Secondary. School supervisors (pengawas) also have their own bodies known as School Supervisor Working Deliberative Group (MKPS). These various groups generally operate at both the neighborhood (gugus/sekretariat) and district/municipality (kabupaten/kota) levels and typically include not only teachers among their membership but also officials from the local education agency.

Most representatives from these groups with whom we met indicated that their respective groups met regularly and had fairly well-organized programs of activities. But generally these tended to be oriented more towards dissemination of and discussion about changes in national or local government education policy than activities aimed at enhancing teachers' subject knowledge and pedagogical skills. One commonly mentioned example was the introduction of the new school curriculum in 2013.

In one case, the head of an MGMP for senior secondary economics teachers appeared to be using his position for rent-seeking purposes in broad accordance with the franchise model. He told us that the MGMP funded training for teachers by drawing on funding from two main sources: the local education agency and local private universities. In general, he was not keen on using the education agency funding because doing so involved a lot of administration. But he still applied for this money because he did not want to get the education agency off-side. For the most part, the MGMP carried out training programs in conjunction with local private universities (in particular low-ranking ones struggling to attract students). Typically, these programs were held as part of these universities' student recruitment drives and involved three components: discussion among MGMP members about substantive issues; contributions by university lecturers related to these issues; and a marketing pitch from the university. The teachers invited to participate in these sessions were generally those from public schools and private schools with large student enrollments and hence the most lucrative recruitment grounds for the private universities.

The third constraint has been the fact that democratization has opened up new opportunities for teachers to challenge teacher management reform. It has done so in several ways:

- By allowing the PGRI greater autonomy from the government. As noted above, under the New Order, the PGRI was a corporatist institution that served to limit independent teacher activism. Since the fall of New Order, it has withdrawn from Golkar and declared itself officially non-partisan in party political terms. At the local level, it has remained closely entwined with government. It is common, for instance, for senior officials in local education agencies to be elected as head of the district/municipal arm of the PGRI. In District B, the link between government and the PGRI is so strong that it is the bupati's wife who is the current head. But, at the national level, the PGRI's repositioning as a formally independent institution has enabled it to take a more critical stance visà-vis government policy and particularly that related to teachers. It has, for instance, publicly challenged the notion that Indonesia has an excess number of teachers; argued that improvements in teacher quality should be linked to 
improved teacher pay (especially via the government's certification program); and contended that teacher redistribution should not be carried out as a form of punishment (see, for instance, PGRI 2015).

- By enabling the establishment of new organizations representing guru honor. The PGRI claims to represent all teachers including guru honor. But, in general, it is seen as prioritizing the interests of guru PNS over guru honor. This, along with greater freedom of organization since the fall of the New Order, has created space for the emergence of rival teacher representative organizations focusing on the latter set of teachers. Examples include the Indonesian Honorary Employees Community (KTSI), the Honorary Teachers' Communication Forum (FKGH), and the Indonesian Honorary Teachers' Association (IGHI). As with the PGRI, it is unclear how genuine or effective these organizations are in representing the interests of their members. Typically, such organizations endeavor to exercise leverage over government policy through engagement with the media and local and national demonstrations, although in some cases they also try to do so through deals with local politicians whereby they trade policy support and access to government grants for help in mobilizing votes. In general, these organizations have focused their activism in relation to teacher management on two specific issues: i) upgrading guru honor to civil servant status and ii) improving guru honor pay.

- By enabling the emergence of independent teacher trade unions: In addition to new guru honor organizations, the post-New Order period has also witnessed the establishment of a host of independent teachers unions such as the FGII, FAGI, and FSGI. These organizations have positioned themselves as opponents of the government's education policies and been particularly vocal over issues such as corruption in school management and the perceived 'privatization' or 'corporatization' of education. Ideologically, they have drawn on left-wing and sometimes radical critiques of neoliberalism that emphasize notions of human rights and social justice. They have made extensive use of the media in promoting their cause, especially professionally-run national newspapers. Occasionally, they have held public demonstrations. They have tended to be based in major urban centers with independent media but not in rural or remote areas where the local media tends to be more closely aligned with local government. Some of these organizations have close links to prominent Jakartabased human rights and anti-corruption NGOs, most notably the Human Rights Foundation (LBH) and Indonesia Corruption Watch (ICW), and Jakarta-based education activist networks such as the Education Forum and the Education Coalition. As we will see below, some of these organizations have expressed support for specific teacher management reform measures in their respective local areas, particularly where it has served their agenda of combatting corruption in school management and promoting rights and social justice. But, otherwise, they have been critical of key central government policies in this area in particular the Five Ministerial decree issued in 2011 (discussed below) (see, for instance, Pahlevi 2012).

- By creating greater scope for teachers to successfully lobby national and local political and bureaucratic elites. The advent of genuinely competitive elections at both the national and local levels, including for executive as well as legislative 
positions, has provided an opportunity for teachers to leverage their electoral importance for advantage. They have accordingly targeted aspiring politicians within the education bureaucracy (MoEC and local agencies), members of national and regional parliaments (DPR and DPRD), and local executives (i.e. bupati or mayor). In some cases, such lobbying has entailed collective action by teacher representative organizations. In other cases, it has been more individualized in nature and tied to specific decisions related to, for instance, teacher transfers. In the later cases, teachers have been able to make use of their respective social and political networks-for instance, family, friendship, or clan relationships to political and bureaucratic figures-and, in some instances, the support of school communities. According to the Chair of the DPRD in Municipality B, most of the complaints that he receives in relation to teacher transfers typically involve appeals from parents of children at sekolah favourit and similar schools indicating that they do not want to lose favorite teachers. ${ }^{18}$

- By creating new judicial pathways for challenging government policy: Judicial corruption, incompetence and inefficiency have remained central features of Indonesia's court system despite democratization. However, democratization and judicial reform have produced enough change in the way in which this system operates that it has become a viable mechanism through which dissident or disaffected teachers as well as NGO activists can challenge government education policy. At the national level, the Constitutional Court (Mahkamah Konstitusi) and Supreme Court (Mahkamah Agung) have been particularly important institutions in this respect because of their ability to rule on the constitutionality of laws and government regulations respectively (Rosser and Curnow 2014; Rosser 2015). At the local level, these actors have had the option of going to the local State Administrative Court (PTUN) which has authority to rule on the legality of administrative decisions related to teacher management such as teacher transfers and the periodization of school principals. This strategy has arguably represented a last resort but, as we will see below, has been used or threatened in some cases.

The overall effect of this political context has been to severely limit the extent to which technocratic elements and their donor supporters have been able to promote teacher management reform. Overwhelmingly, commentators on teacher management reform have argued that the central government has made very little progress at all in improving teacher distribution and quality and controlling teacher costs (Ilfiyah et al 2015; Al-Samarrai et al 2012; Chang et al 2014; World Bank 2015). However, as we will see below, the disaggregated picture is more nuanced. While technocrats and donors may have made limited overall progress, they have achieved some important wins in relation to particular teacher management issues. In the following section, we present this more disaggregated picture by analyzing the political and social dynamics around several specific teacher management issues drawing in many cases on material from our four case study regions. In so doing, we seek to identify the political and social conditions that have made teacher management reform possible even within the context of an overall political and social environment that has been antithetical to reform.

In this connection, as noted earlier, we suggest that teacher management reform has been possible where:

${ }^{18}$ Interview, August 2015. 
1) the central government has had at its disposal or been able to devise policy instruments that are effective in disciplining local governments and it has maintained a commitment to these policy instruments even in the face of opposition;

2) local civil society groups are present and able to launch effective public campaigns demanding reform, exploiting their ability to access the independent media and, if necessary, the courts; and local governments are able to find effective ways of buying off the losers from reform;

3) mid-level government officials, especially ones at the local education agency, have judged that reform initiatives can be exploited for patronage purposes; secured support from above; and together with senior officials devised effective strategies for managing the politics of reform (by, for instance, securing the support of the DPRD and buying off the losers from reform);

4) reform-minded district leaders have been elected providing an imperative for education agency officials to design reform programs and the latter have had access to relevant ideas and policy advice as a result of contact with donors; and/or

5) teachers and the patronage and political networks of which they are part have stood to lose little from reform in the first place.

\section{Specific Issues}

\subsection{Teacher Numbers and Cost}

The introduction of a new Constitutional requirement for Indonesian governments at all levels to spend at least 20 percent of their respective budgets on education has, as noted earlier, witnessed a massive increase in total government spending on education. Much of this new spending has gone to teachers' salaries as a result of three concurrent developments: strong growth in recruitment of new teachers at all levels of the school system; large increases in teacher pay, particularly as a result of the introduction of a new certification program in the late 2000s (see below); and the conversion of large numbers of guru honor to guru PNS, producing a substantial increase in both their pay and their cost to the budget (World Bank 2013: 44-45).

This privileging of teacher employment and salaries as an item of education expenditure has been consistent with the interests of political and bureaucratic elites at both the central and regional levels as well as, of course, teachers themselves. For political and bureaucratic elites at the central level (especially incumbent or aspiring politicians), the recruitment of additional teachers and increases in their pay has been a way of securing political support within the school system and potentially votes at election time. For officials within MenPAN, these policies have represented an opportunity to sell access to a new form of state largesse- that is, additional civil service positions. For officials at the local level, these policies have represented an opportunity to expand and consolidate local patronage and political networks by capturing this new form of largesse and the rent-seeking opportunities it provides. For teachers themselves, these policies have entailed higher incomes through better remuneration and, in the case of guru honor who have been upgraded to PNS status, both higher incomes and better conditions of employment. 
Technocratic officials in the central government and their donor supporters have not contested the government's decision to increase spending on education-indeed, they argued forcefully in the early post-New Order period that the government should spend more on education in order to improve access to and the quality of education and enhance the country's economic competitiveness (see, for instance, World Bank 1998; Jalal and Musthafa 2001). However, they have queried the efficiency of increased government spending on teachers' salaries noting that growing teacher numbers has lowered teacher-student ratios to the point where further increases in teacher numbers are unlikely to produce any significant educational gains (World Bank 2013: 101; Al-Samarrai et al 2012; USAID Prioritas 2015). They have also expressed concern about both the fiscal sustainability of further rises in government spending on teacher salaries and the potential for such spending to crowd out other important areas of investment (Jalal et al 2009: 169; Chang et al 2014: 161-162).

With the fiscal implications of these policies becoming increasingly widely recognized, technocratic officials were able to secure a moratorium on new civil service appointments in 2011 in regions where government spending on salaries exceed 50 percent of the regional government budget. Announcing the policy, Finance Minister Agus Martowardoyo stated that: 'The high share of personnel costs erodes the funding available for capital expenditures. This means we have reduced budgets for social services and infrastructure development' (Jakarta Post 2011). This moratorium appears to have remained in place in many regions for several years.

In interviews with various local government officials in District A, District B, and Municipality B - all districts that have been subject to the moratorium-we heard that the moratorium was leading to a sharp reduction in the number of guru PNS within their respective regions and making these regions more reliant upon guru honor to deliver the required number of classes. ${ }^{19}$ Indeed, the head of the regional civil service agency in District A declared that his district would be a facing 'teacher crisis' in 2019 if the moratorium continued because of the impending retirement of teachers who were recruited in the late 1970s. ${ }^{20}$ These teachers-many of whom were employed through the issuance of a presidential instruction (inpres) and are consequently referred to as guru inpres - were extremely large in number because their employment was a key part of the New Order's effort to dramatically expand the school system using proceeds from the oil boom. Their forthcoming retirement is thus expected to lead to a significant reduction in teacher numbers. In two districts-District A and District B-we heard that local education agencies and/or regional civil service agencies were beginning to plan around longer working weeks as a way of dealing with the looming teacher shortage.

The PGRI has made similar claims about a teacher crisis, arguing forcefully that the country in fact is facing a severe teacher shortage (PGRI 2015; Kompas 2015b). For it, the crucial relevant figure is not student-teacher ratios but rather the number of classes (rombel) taught by teachers who have not yet been granted civil servant status. Using this basis of calculation, it has argued that the country needs another 400,000 teachers at the primary level alone (PGRI 2015).

Representatives of some regional governments have pushed back against the moratorium suggesting that it is too blunt an instrument for trying to reduce the cost of teachers' salaries (Boediwardhana 2011). The PGRI has claimed that the moratorium breaches the 2005 Teachers Law to the extent that the law requires the government to fulfill teachers' needs including in

\footnotetext{
${ }^{19}$ Interviews with the Secretary of the District A Education Agency; head of the District B Education Agency; and head of the Municipality B Education Agency.

${ }^{20}$ Interview, June 2015.
} 
terms of overall numbers (Kompas 2015b). Finally, organizations representing guru honor have continued to organize regular demonstrations at both local sites and in Jakarta demanding that these teachers get a better deal including conversion to PNS status. In some regions, the result has been the introduction of new allowances for guru honor-in one, for instance, the provincial government has recently introduced a new monthly allowance for guru honda of $\mathrm{Rp} 50,000 .^{21}$

But, so far, the central government has refused to budge on the moratorium, having little room to manoeuver in the context of slowing economic growth and a tight budget. In fact, it has recently lowered the level at which the moratorium becomes effective from 50 to 40 percent of the regional government budget. It has also decided recently to reduce the proportion of BOS funds that can be used to employ guru honor from 20 percent to 15 percent, making it harder for schools to continue employing honorary staff to replace lost guru PNS.

In the case of the moratorium, the central government's intransigence undoubtedly reflects the fact that it is paying the bill for teachers' salaries while the political and patronage benefits of guru PNS appointments accrue largely to local political and bureaucratic elites. In the case of the cuts to the BOS funds, it also probably reflects the fact that this move has attracted little open opposition from teachers and their unions - certainly much less than the moratorium. This may be because, as a number of school principals noted in interviews, schools have so far been able to retain guru honor by reassigning them to non-teaching duties. Principals appeared during these interviews to have had a firm reluctance to dismiss guru honor for being surplus to requirements, a pattern of behavior consistent with the logic of patronage networks.

In sum, then, the policy issue of teacher numbers and costs illustrates that reform is possible where the central government uses or devises policy instruments that are effective in disciplining local governments and maintains a commitment to these instruments even in the face of opposition.

\subsection{Employment and Promotion}

The issue of teacher employment and promotion presents a similar story. As noted above, MenPAN officials have been accused of exploiting their control over the number and type of new guru PNS positions awarded to regions to 'sell' civil service positions to regional elites looking for additional patronage resources. At the same time, local political and bureaucratic elites have had control over teacher and, in particular, school principal appointments enabling them to build patronage and political networks capable of generating sizeable rents, distributing patronage, and mobilizing significant numbers of votes at election time. They have been able to build such networks by i) appointing friends, family-members, and political supporters to teacher positions and in particular school principal positions or alternatively selling such positions to the highest bidder rather than appointing the best qualified or most capable candidates; ii) promoting such individuals further upward into the local education agency where even greater rent-seeking opportunities exist; and iii) ensuring that political enemies are demoted, di-nonjob-kan, or rotated (dimutasi) to less lucrative and more remote schools. The overall effect has been to undermine the quality of both Indonesia's teachers and school principals.

${ }^{21}$ This policy has in turn triggered demands from guru honor appointed by school principals to have their status changed to guru honda. Interview with a PGRI activist representing honorary teachers, Municipality B, August 2015B. 
To help address this problem (and similar problems in other areas of civil service recruitment), technocratic officials in the central government led by Vice-President Boediono, the Anticorruption Commission (KPK) and anti-corruption NGOs such as ICW began pushing for more transparent and 'objective' civil servant recruitment processes (Lampost.co 2013; Manggiasih 2013). They were supported in this endeavor by the then Minister for the Empowerment of the State Apparatus, Azwar Abubakar (Manggiasih 2013). The result was the introduction of new system of civil servant recruitment that both reduced the role of regional governments in the recruitment process and tried to make the process less susceptible to corruption and favoritism. The key reforms were the introduction of a computer-based competency test (CBT) to replace the previously written test - the former being less easy to manipulate than the latter-and the transfer of responsibility for selection of successful candidates from regional governments to the central government. ${ }^{22}$

The effect of these reforms with regards to teacher recruitment appears-at least from the evidence we encountered-to have been dramatic. In interview, the head of the education agency in the fifth district mentioned earlier, told us that many civil servant teachers now being employed in her region were coming from a neighboring region rather than from local areas, as in the past, because they tended to be better academically and hence scored higher on the CBT. She said that the selection process was now so difficult to manipulate that the bupati's son/daughter (anak) had been unable to secure a civil service position, something that would have been more or less automatic in the past. Media reports suggest that this has also been the case in other regions (see, for instance, Tribun Pontianak 2013 and Batampos 2014).

To the best of our knowledge, there has not so far been any significant pushback from regional elites in relation to these changes, meaning that there has been little pressure on the central government to return to the previous system. As with the moratorium, then, the central government has maintained its commitment to this reformist policy instrument. But the cost of the changes to local elites-particularly in terms of their ability to lubricate patronage and political networks - is clear. It is consequently possible that there may be concerted opposition to the change particularly if it triggers local protests about 'outsiders' taking local jobs.

\subsection{Teacher Certification}

Technocratic officials have sought to improve teacher quality by promoting improved preservice training for teachers at LPTK, in particular via the application of more stringent accreditation processes requiring LPTK to, for instance, develop curricula providing an appropriate balance between theory and practice (Jalal et al 2009: 135). But their principal strategy for improving teacher quality has focused on trying to improve the skills and commitment of existing teachers through the introduction of a new certification program linking teachers' salaries to their qualifications, competencies, and workloads. The World Bank-Bappenas Task Force that addressed teacher management issues in the late 1990s explicitly recommended that the government link future pay raises for teachers to 'an evaluation of professional criteria which connect directly with professional development, new skill acquisition, orientation change and learning practice, and collaboration for self-development' (Jalal and Mustafa 2001: 152). Coinciding with demands by the PGRI for new regulations providing for the welfare and protection of teachers (which it saw as a crucial step towards

${ }^{22}$ Interview with anti-corruption activist, Jakarta, May 2015. 
securing increased remuneration for teachers), technocratic efforts to promote improved teacher quality led to the passage of Law 14/2005 on Teachers and Lecturers. This law made it compulsory for Indonesian teachers to be certified and, in conjunction with a series of subsequent government regulations, specified the conditions under which they would be deemed to meet certification requirements and receive an associated professional allowance equal to teachers' base salary, effectively doubling their income.

Led by Fasli Jalal, then Director-General of Quality Improvement of Teachers and Education Personnel (LMPTK), and with World Bank support, a team within MoNE developed a model for assessing teacher competence. They determined that teachers would be deemed competent if they: i) held the equivalent of a four year higher education degree (S1); ii) taught a minimum 24 periods per week; and iii) could demonstrate competence in teaching as assessed in the classroom by trained assessors and through a program of individualized in-service training. ${ }^{23}$

This model ran up against opposition from the PGRI and other teacher unions which saw the competency tests as a threat to increased pay for many of their members-something they in turn saw as a 'right'. Led by the PGRI, they lobbied the national parliament-which had control over the budget for implementation of the competency tests - to have this element of the model thrown out, presumably threatening to mobilize the teacher vote against politicians who stood in their way. The result was a compromise whereby teacher competence was assessed in two stages. In the first stage teachers prepared a portfolio of achievement comprising documents such as personal references, publications, certificates of attendance at ins-service courses, model lesson plans. These were then be evaluated by local teacher education institutions selected by MoNE. Teachers whose portfolios were approved proceeded directly to certification. In the second stage, teachers whose portfolios were not approved were required to attend a 90-hour training program and assessed on its content. Teachers who passed the associated test then proceeded to certification as well (Chang et al 2014: 30).

The compromise system proved to be problematic in practice as corrupt behavior on the part of teachers, education agency officials, and staff at teacher education institutions undermined the assessment of portfolios and in the 90-hour training program. Teachers were soon able to buy portfolios on the street while virtually all participants passed the 90-hour program. In response, the central government changed the certification process so that the portfolio assessment became a minor component and a 90 hour program of professional development became the principal pathway to certification. But this had little impact on pass rates. ${ }^{24}$ Not surprisingly, numerous studies of the impact of the certification program have indicated that it has had led to little, if any, improvement in teacher subject knowledge or pedagogical skills or student learning (see, for instance, Chang et al 2014; World Bank 2015).

The central government subsequently introduced a Competency Test for teachers (Uji Kompetensi Guru) in 2012 aimed at assessing teachers' subject knowledge and pedagogical skills. Conducted using multiple choice questions and done in part on-line, the results have provided further evidence of low teacher quality. Of 1.6 million teachers assessed in 2015, 1.3 million gained a score of below 60 on a scale from 0-100 (Kompas 2015a). The teacher unions, including the PGRI, have strongly opposed this test, apparently fearing that it will eventually be incorporated into the certification process in some way (Sugiharto 2012). The FSGI, supported by the FGII, ICW, LBH and the Education Coalition, even went to the point of trying

\footnotetext{
${ }^{23}$ Interview with an informed source, January 2013.

${ }^{24}$ Interview with an informed source, January 2013. See also World Bank (2015: 15).
} 
to challenge the test via a judicial review request in the Supreme Court (Liputan6.com 2012). The FSGI's Retno Listyarti has likened the Competency Test to 'malpractice' arguing that implementation of the test has often been full of errors (e.g. incomplete questions, typographical errors, inappropriate questions given teacher's field of expertise) and that some teachers have to leave their classes and bear significant costs simply to take the tests (see, for instance, Ayuningtias 2012). In the face of such concerted resistance and with fiscal sustainability issues being addressed through the moratorium, the central government has so far baulked at incorporating the test into the certification process.

Teachers unions have also expressed concern about the way in which the certification program is administered, noting many districts are slow in paying the professional allowance to teachers and that some teachers face difficulty in meeting the 24 teaching periods per week requirement. ${ }^{25}$ But with the program generating huge unconditional pay rises for teachers, they have staunchly defended it, framing the pay rises as essential for improved educational quality and a matter of teachers' rights (see PGRI 2015). In this position, they have received strong support from regional political and bureaucratic elites, especially local education agencies, for whom the pay rises represent an opportunity to lubricate networks of corruption and patronage. ${ }^{26}$

It is possible that the teacher certification program has had positive 'side-effects', for instance, with regards to teacher absenteeism. A recent ACER/SMERU study on teacher absenteeism in Indonesia found that between 2003 and 2013 absenteeism rates at primary schools fell from 19 percent to 10-11 percent (McKenzie et al 2014). One possible explanation for this is that, by linking teacher pay to the number of hours teachers carry out face-to-face instruction, the certification program has incentivized teachers to turn up to work more often than before. Several of our informants noted that it was commonplace for school principals to manipulate teacher attendance data-specifically, that submitted through Dapodik, MoEC's education database, for the purposes of determining eligibility for the professional allowance. ${ }^{27}$ But the methodology employed in the ACER/SMERU study accounted for this possibility through direct observation of teachers in the classroom and cross-checking teacher attendance against teacher rosters suggesting that the improvement in teacher absenteeism rates is real. The teacher certification program may also have had positive side effects with regards to teacher redistribution, as we will discuss below. However, in terms of its ostensible aim-improving teacher subject knowledge and pedagogical skills-the evidence so far suggests that it has failed.

In sum, then, in terms of our concern with the political and social conditions that are conducive to teacher management reform, the certification issue illustrates again the crucial role of central government commitment to reformist policy instruments that seek to precipitate change at the local level, albeit indicating in this case the problems when such commitment evaporates.

\subsection{Periodization of School Principals}

\footnotetext{
${ }^{25}$ Suryahadi and Sanbodho (2012).

${ }^{26}$ Interviews with local education agency officials in District A, Municipality A, District B, and Municipality B, May-August 2015.

27 The typical example given was of a guru PNS being recorded as teaching a class when in fact it was taught by a guru honor.
} 
The entrenched nature of patronage and political networks linking schools to regional governments has resulted in, among other things, long tenures for many teachers and school principals at particular schools. The general pattern seems to be that, so long as teachers and school principals maintain good relations with officials in the local education agency-a function of their willingness to provide upeti (tribute) to these officials and mobilize votes as instructed at election time - they have been permitted to work at schools near their friends and family and to remain there for extended periods even if this results in a gross mal-distribution of teachers. At the same time, teachers and school principals aspiring to positions within the local education agency and perhaps beyond or looking to secure greater rent-seeking opportunities have been-again so long as they maintain good relations with officials in the local education agency-recruited into positions in sekolah favorit. Those who remain in favor have then either been promoted upward into the local education agency or permitted to remain at sekolah favorit and enjoy the financial benefits that accrue from positions there. This in turn has meant long tenures for some teachers and school principals at these schools as well.

To help address this situation, MoNE issued a decree early in the post-New Order period that limited the number of periods school principals could serve. ${ }^{28}$ This decree reflected the reformist sentiment that accompanied the transition to democratic rule in the late 1990s and, in particular, Constitutional changes limiting the number of terms that the President and VicePresident could serve. It was also consistent with similar regulations introducing restrictions on the tenure of university rectors. This decree was replaced in 2010 by a minister regulation on the appointment of teachers as school/madrasah principals. ${ }^{29}$ Under this regulation, school principals are defined as teachers who have been given additional responsibilities. It stipulates that school principals can serve a maximum of three four-year periods and to get a third period, a school principal's performance had to be deemed 'special' (istimewa). S/he also has to be prepared to move to a school with a lower accreditation rating.

Generally speaking, these changes in national regulations appear to have had little effect at the local level, at least until recently. In our sample of four districts/municipalities, for instance, only the government of Municipality A moved to implement the 2003 ministerial decree. In 2006, it issued a bupati regulation providing a local legal basis for periodization (periodisasi), as the policy has become known. It then enforced this regulation in 2008 and 2012, resulting in the discontinuation ${ }^{30}$ of over 500 school principals in 2012 alone. Otherwise, however, regional governments appear to have been immobilized by the challenge that enforcement of periodization regulations has posed to patronage and political networks.

In interviews, various local government officials in Municipality B and District B informed us that they were now just starting to implement the periodization regulations this year. Municipality B discontinued a small group of school principals while we were in the field (JulyAugust 2015). ${ }^{31}$ District B is working up a new local regulation that will provide a legal basis for periodization and intends to enact it and implement it in the near future. ${ }^{32}$ It is not entirely clear what has led to this change. But one possibility is that it is connected with the certification

\footnotetext{
${ }^{28}$ See Keputusan Menteri Pendidikan Nasional Nomor 162/U/2003 tentang Pedoman Penugasan Guru Sebagai Kepala Sekolah.

${ }^{29}$ See Peraturan Menteri Pendidikan Nasional Nomor 28 Tahun 2010 tentang Penugasan Guru Sebagai Kepala Sekolah/Madrasah.

${ }^{30}$ The word commonly used in Indonesian is diberhentikan-literally, to be brought to a stop. The school principals were not dismissed because, as we note below, virtually all remained employed in alternative civil service roles.

${ }^{31}$ Interview with the Regional Secretary, Municipality B, August 2015.

${ }^{32}$ Interview with the current head of education agency in District B, July 2015.
} 
program and, in particular, teachers' eligibility for the professional allowance. According to a recent media report, school principals and teachers in Cianjur, West Java, have experienced delays in receiving the professional allowance where school principals have been in place for too long (Pikiran Rakyat 2015). ${ }^{33}$

In Municipality A, the earlier implementation of the periodization requirements reflected the fact that FAGI and FGII, two independent teachers' groups, and the Municipality A Education Coalition (KPKMA), an NGO group-all of which have a strong local presence-launched a sustained campaign to demand implementation of the periodization regulations beginning in the early to mid-2000s. This campaign was aimed at trying to i) break the networks of corruption that exist between schools and the local education agency; ii) in so doing, improve the quality of public school management; and iii) provide opportunities for the next generation of teachers to gain promotion. ${ }^{34}$ It attracted significant media attention and entailed a threat to take the local government to the State Administrative Court (PTUN). The latter was particularly important to the extent that it opened up the possibility that local education agency officials could be subject to extortion by the court's judges. ${ }^{35}$

Having decided to implement periodization, the issue for the local government then became how to manage the politics around its implementation. Periodization evoked some resistance from school principals. ${ }^{36}$ In the end, this was defused by promoting most outgoing school principals to pengawas (supervisor), a decision that preserved their income levels (but also reduced any prospective budgetary savings from the policy). Only a small number of school principals opted to return to teaching duties. At the same time, three school principals were not discontinued: two who headed sekolah favorit and one with strong political connections. ${ }^{37}$ The chair of a Primary School Principals Working Group (KKKS) in District B told us that primary school principals in his area had made it clear to the head of the local education agency branch (UPTD) that they would prefer the government adopt this same solution, rather than returning principals to teaching, when periodization is implemented in that district. ${ }^{38}$

In contrast to the three previous policy issues examined here, then, the issue of periodizationand in particular the experience of Municipality A in relation to this issue-suggests that teacher management reform can occur at the local level when three conditions are met: i) independent civil society groups are active; ii) they are able to launch effective public campaigns demanding reform, exploiting their ability to access the independent media and, if necessary, the courts; and iii) local governments are able to find effective ways of buying off the losers from reform. At the same time, the experiences of Municipality B and District B suggest that teacher management reform is possible when it aligns with the needs of local political and patronage networks, in particular, the need for local elites to ensure that teachers continue, as clients within these networks, to receive all monies that are due to them.

\footnotetext{
${ }^{33}$ The cause of this delay is unclear but it is possible that it is related to the introduction of Dapodik, MoEC's new education database. According to a local education agency official in the fifth district, Dapodik will not allow a school principal's name to be entered for a second four year period at the same school, jeopardizing teachers' eligibility for the professional allowance if the school principal remains in place for more than one term. This has led to a local policy of rotating school principals every four years.

${ }^{34}$ Interviews with activists from FAGI/FGII, May 2015, and KPKMA, June 2015.

${ }^{35}$ Interview with FAGI/FGII activist, Municipality A, May 2015.

${ }^{36}$ Interview with FAGI/FGII activist, Municipality A, May 2015.

${ }^{37}$ Interview with FAGI/FGII activist, Municipality A, May 2015.

${ }^{38}$ Interview, July 2015.
} 


\title{
5.5 Teacher Redistribution
}

The entrenched nature of patronage and political networks linking schools to regional governments has, for the reasons mentioned above, also resulted in a severe mal-distribution of teachers. As Al-Samarrai et al (2012: 2) have explained, this mal-distribution has involved not simply unevenness in the number of teachers across regions but also in the quality of teachers:

\begin{abstract}
It is common for rural and remote schools to have teacher shortages while urban schools have more teachers than national staffing standards dictate. Moreover, more qualified and experienced teachers are frequently concentrated in wealthier urban areas. For example, over half of all primary and junior secondary school teachers in urban areas have a four year university degree compared to only $20 \%$ of teachers in rural remote locations.
\end{abstract}

To address this problem, the Education Committee chaired by Vice-President Boediono agreed that five central government ministers (the Minister of National Education, the State Minister for the Empowerment of the State Apparatus and Bureaucratic Reform, the Minister of the Interior, the Minister of Finance, and the Minister of Religious Affairs), all of whom were represented on the Education Committee, should issue a joint regulation instructing regional governments to redistribute teachers more equitably (Kompas 2010b). Issued in 2011, the Five Ministerial Decree (SKB 5 Menteri), as the regulation has become known, ${ }^{39}$ threatened regional governments with a range of sanctions if they did not comply. These included the withdrawal, in part or full, of education funding to regional governments; delays in the granting of new civil service teacher positions (formasi guru PNS) to regional governments; and delays in the provision of 'balancing funds' (dana perimbangan) to regional governments. ${ }^{40}$

As with the earlier periodization regulations, however, this regulation appears to have had little effect at the local level: as various commentators have noted, regional governments have in general taken little action in response (Ilfiyah et al 2015; Republika 2014). This does not appear to have reflected a lack of technical capacity at the local level to manage teacher redistribution: in general, our interviews with local educational agency officials suggested that they have the required data and analytical capacity to redistribute teachers in a more efficient and effective way.

Rather, the obstacles appear to be political in nature. In part, the lack of action in response to the SKB 5Menteri appears to be because regional governments have not seen the threats it contains as credible: one of our informants noted that they would be disastrous if implemented. ${ }^{41}$ In part, it is because they have baulked at the political challenges that teacher redistribution entails. For reasons outlined above, teacher redistribution represents an attack on the interests of political and bureaucratic elites and teachers, both of whom have had significant capacity to push back against unwanted change. In the case of political and bureaucratic elites, this is because they have controlled the local state apparatus and its policy-making and implementation powers. In the case of teachers, it is because their electoral strength and political and social networks have given them the ability to effectively lobby local politicians,

\footnotetext{
${ }^{39}$ Its full title is Peraturan Bersama Menteri Pendidikan Nasional, Menteri Negara Pendayagunaan Aparatur Negara dan Reformasi Birokrasi, Menteri Dalam Negeri, Menteri Keuangan, dan Menteri Agama Nomor 05/X/PB/2011, Nomor SPB/03/M.PAN-RB/10/2011, Nomor 48 Tahun 2011, Nomor 158/PMK.01/2011, Nomor 11 tahun 2011 Tentang Penataan dan Pemerataan Guru Pegawai Negeri Sipil.

40 'Balancing funds' are funds provided by the central government transfers to regional governments to enable the latter to carry out their functions under decentralization. They consist of general allocation funds (DAU), DAK, and Revenue Sharing Funds (dana bagi hasil). See Peraturan Pemerintah Nomor 55 Tahun 2005 tentang Dana Perimbangan.

${ }^{41}$ Interview with the Regional Secretary (Sekda), Municipality B.
} 
especially members of the DPRD and regional executives (i.e. the bupati or mayor). They have also, on occasion, been able to access the courts if necessary.

In a small number of cases, district governments have nevertheless introduced programs of teacher redistribution (Ilfiyah et al 2015; USAID Prioritas 2014). But the introduction of these programs has not necessarily been a response to the SKB 5 Menteri nor motivated by technocratic/donor concerns. Where these programs have embodied such concerns, it has been because donors have been active within the region and played a crucial role in putting ideas on the table.

The experiences of our four focus districts illustrate the dynamics at work and the different outcomes that have prevailed at the regional level.

\subsubsection{Municipality A}

Although Municipality A is a municipality and, as such, lacks remote and rural areas, it still has significant distribution problems. Several informants noted that the city has schools with too many teachers and others with too few, particularly with regards to subject teachers (see also Annex One $)^{42}$ Yet the city government has so far done little to address teacher distribution problems, notwithstanding the fact that under its mayor, who was elected in 2013, 'redistribution of quality' (pemerataan mutu) within the school system is a key plank of the local government's education policy agenda. The mayor has put in place some measures - such as the reintroduction of school catchment areas and caps on senior secondary school feesaimed at achieving this objective. But he has so far failed to implement teacher redistribution.

The city government's initial response to the SKB 5 Menteri-made under the previous mayor-was to kick the problem downstairs. In a Circulating Letter (Surat Edaran) issued in July 2012, the then head of the local education agency instructed school principals to deal with the problem by coordinating among themselves. ${ }^{43}$ His replacement as head, who was appointed by the current mayor, appears to have more ownership of the problem. He has tried to produce local regulations providing for redistribution. But these have so far been held up in the legal section (bagian hukum) of the education agency. The problem, according to informed sources, has been that mid-level officials within the agency have been effectively sabotaging moves to rotate or redistribute teachers reflecting their interest in maintaining the patronage and political networks that link them to schools and, in particular, principals and teachers in favorit schools most likely to lose from redistribution. ${ }^{44}$

\subsubsection{Municipality B}

Like Municipality A, Municipality B has significant teacher distribution problems despite, as a municipality, lacking remote and rural areas. Again, like Municipality A, these appear to center on the distribution of subject teachers (see Annex One). ${ }^{45}$ Between 2008 and 2013, the regional

\footnotetext{
${ }^{42}$ Interviews with the head of the Municipality A Education Agency, May 2015, and FAGI/FGII activist, May 2015.

${ }^{43}$ Title of the regulation withheld because it identifies the municipality.

${ }^{44}$ Interviews, Municipality A, May 2015.

${ }^{45}$ Interviews with the head of Municipality B Education Agency, and the Branch head for SMP, SMA and SMK Municipality B, August 2015.
} 
government did little to address this problem, the mayor and his regional secretary taking the view that redistribution was unnecessary since the city had too many teachers. ${ }^{46}$ The Education Board made a recommendation to the education agency at the time that it carry out a mapping of teacher needs and allocate teachers to schools accordingly. But this was never taken up. ${ }^{47}$ One branch head (kepala bagian) in the education agency official explained that the issue of teacher redistribution had been discussed extensively within the education agency but that there had so far been little willingness to tackle the problem in any systematic or serious way. Indeed, they had floated the idea of kicking the problem downstairs to the UPTD. He stated that the key obstacle was the political challenges involved in teacher redistribution. ${ }^{48}$

Since 2013, it appears that the city education agency has, however, started to change direction on the issue. 2013 saw two important developments. The first was the election of a new mayor although, because of a Constitutional Court challenge to the election result, he did not take up the job until late 2014. His choice as head of the local education agency told us that teacher redistribution is one of his top priorities indicating that the agency may be more active in this area in future. ${ }^{49}$ Having only been in the job for four months at the time of interview, however, he had not yet had the chance to make much progress so far.

The second development was the introduction of new and more demanding technical guidelines (juknis) for the professional allowance associated with the certification program. According to the head of the junior and senior secondary education branch in the education agency, the tighter requirements imposed by these guidelines raised the risk of a negative State Financial Audit Agency (BPK) or State Finance and Development Supervision Agency (BPKP) ${ }^{50}$ audit finding if city claims regarding the number of teachers who are eligible for the professional allowance could not be fully substantiated. This in turn could trigger cuts to central government transfers to the city government. Beginning in 2013-2014, he has consequently carried out a detailed mapping of teacher needs in junior and senior secondary schools and been careful to ensure that teacher transfers were done in accordance with schools' genuine need for teachers. In contrast to the SKB 5 Menteri, then, it would appear that, at least for this official, the new technical guidelines for the professional allowance combined with BPK/BPKP audit processes posed a credible threat to the city government even if the introduction of the new guidelines may not have been directly intended to affect teacher distribution.

\subsubsection{District A}

District A is a large district that includes urban and rural areas, some of which are remote. Like Municipality A and Municipality B, it has had significant teacher distribution problems, particularly at both primary and junior secondary level (see Annex Two). In contrast to these municipalities, however, it has been relatively active in redistributing teachers as well as changing their type, level and/or function (jenis, jenjang, fungsi) ${ }^{51}$ for several years.

\footnotetext{
${ }^{46}$ Interviews with former mayor of Municipality B and former head of the city education agency and currently (August 2015) Regional Secretary, Municipality B, August 2015.

${ }^{47}$ Interview with the head of the Education Board, Municipality B, August 2015.

${ }^{48}$ Interview, Municipality B, August 2015.

${ }^{49}$ Interview, Municipality B, August 2015.

${ }^{50}$ These agencies are respectively the state external and internal auditors.

${ }^{51}$ Change in type $=$ e.g. maths teacher becoming a science teacher; change in level = e.g. SMA maths teacher becoming an SMP maths teacher; change in function = e.g. teacher moving into an administrative position.
} 
The local education agency began planning for teacher redistribution shortly after the central government issued Government Regulation 74/2008 on Teachers. This regulation established the 24 hour requirement and other eligibility criteria for the professional allowance. The education agency carried out mapping (pemetaan) to establish areas of teacher shortage and excess from 2009 but it was not until 2012 that it actually began to redistribute teachers. Education agency figures show that, of 12,000 PNS teachers working in District A around this time, 454 were moved in 2012, 249 in 2013, 60 in 2014 and 129 in 2015. But the 2012 figure includes 251 who moved at their own initiative between 2009 and 2011, so the real 2012 figure should be $203 .^{52}$ The increase between 2014 and 2015 was made necessary by the introduction of a new national curriculum in 2013 which eliminated some subjects from the curriculum. In the wake of the new curriculum, the education agency carried out a remapping of teacher supply and need to determine areas of shortage and excess. It then reassigned teachers to new types or levels and in some cases new schools so that they could meet the 24 requirement. ${ }^{53}$

The key driving force of change in District A with regards to teacher redistribution has been a concern to help teachers meet the 24 hour and linearity ${ }^{54}$ requirements for receiving the professional allowance attached to the certification program rather than concerns related to budgetary efficiency or educational quality (although the latter have been recognized as potential payoffs). ${ }^{55}$ Change has not been donor-driven. USAID’s Prioritas program, which operates in the district, only became operational there in 2013, well after the government began to move on redistribution, although it has provided some legitimacy to the reforms by garnering international donor, education ministry and media attention (see, for instance, Jawa Pos 2014). ${ }^{56}$

The politics of redistributing teachers in District A had three discrete phases:

- The first phase entailed school supervisors working out that many teachers in District A would be ineligible for the professional allowance unless the local government redistributed them to places and roles that enabled them to meet the requirements of Government Regulation No. 74 of 2008. They did this through discussions with school principals and teachers as part of their supervisory responsibilities, hearing complaints from teachers about being short of hours. They then made a recommendation for teacher redistribution to the head of the education agency's Civil Service sub-section (Kasubag Kepegawaian) through the School Supervisor Working Deliberative Group. ${ }^{57}$

- $\quad$ The second phase entailed the head of the education agency's Civil Service sub-section working in conjunction with the head of the Civil Service Rotation Section (Kabid Mutasi Kepagawaian) at the Regional Civil Service and Training Agency (BKDD) to persuade the head of the education agency, the bupati, the vice-bupati and other senior officials to sign off on a redistribution program. Parallel processes seem to have been

\footnotetext{
52 Interviews with senior education agency officials, District A, June 2015.

${ }^{53}$ Interviews with senior education agency officials, District A, June 2015.

${ }^{54}$ To receive the professional allowance, teachers have to teach subjects that are related to their academic qualifications and field of certification-i.e. teachers with maths qualifications should be teaching maths. This is referred to as linearity (linearitas).

55 This came through particularly strongly in interviews with key actors within the education agency at the time. Their respective positions and roles are discussed in the main text.

${ }^{56}$ For a more general analysis of the way in which local elites exploit donor programs for political advantage, see Choi and Fukuoka (2014).

${ }^{57}$ Interview with a school supervisor and education agency official, District A, June 2015.
} 
going on in the local health agency with regards to PNS health workers (and perhaps other agencies), so it is likely that officials in these agencies were involved as well. ${ }^{58}$ The result was the issuance of bupati regulation providing the legal foundation for teacher redistribution within District A as well as redistribution of other civil servants.

- $\quad$ The third phase entailed the local government engaging in change management- - that is, ensuring that teacher redistribution occurred without provoking a destabilizing or politically damaging backlash from affected teachers. The key elements in this phase were threefold:

i) extensive and early socialization of the policy among teachers. This was carried out through school principals, the PGRI, and direct visits to schools by the then education agency head. In the latter case, the focus was on the opportunities presented by the certification program but the need for redistribution to enable teachers to meet certification requirements was also flagged.

ii) early engagement of the regional parliament (DPRD), particularly the commission responsible for education matters (Komisi 4), to ensure that it was on board.

iii) neutralization of protests by teachers who reacted negatively to proposed moves. It appears that a small number of teachers made individual protests about proposed moves through direct approaches to the education agency or the local parliament. One, a teacher with preman-like tendencies, reportedly placed a gun on the table in his meeting with education agency officials, a clear form of intimidation. Education agency officials say that they successfully neutralized most protests by pointing out the benefits from proposed moves in terms of improving their eligibility for the certification program. If teachers continued to object, they were allowed to stay in their existing positions (although in these cases they did not receive the professional allowance if their teaching load remained below 24 hours or they did not meet the linearity requirements). ${ }^{59}$

The fact that teacher redistribution was so closely linked to the requirements of the certification program suggests that the principal motivations of the supervisors and the mid-level education agency officials who were so crucial in pushing the process forward and the senior officials who ultimately approved teacher redistribution were related to the dynamics of local patronage and political networks. As patrons within the system, they had a concern to ensure their clients at the school level received their due entitlements in order to consolidate political and patronage networks. As rent-seekers within the system, they also had a concern to maximize amount of the money within the school system that is available for potential appropriation.

\subsubsection{District B}

Like District A, District B is a large district that straddles urban and rural areas, some of which are remote; has had significant teacher distribution problems (see Annex Two); and has been relatively active in redistributing teachers. Indeed, of our four regional cases, it has been by far the most aggressive reformer in this respect. Since 2007-2008, the regional government has redistributed almost 3,000 civil servant teachers, accounting for a very large proportion of the

\footnotetext{
${ }^{58}$ Interview with senior education agency officials, District A, June 2015.

${ }^{59}$ Interviews with senior education agency officials and a former head of the education agency, District A, June 2015.
} 
teaching labor force. The numbers redistributed were: 644 in 2008, 0 in 2009, 344 in 2010, 360 in 2011, 552 in 2012, 502 in 2013, 166 in 2014, and 331 in 2015. Some teachers who were transferred were moved to isolated parts of the district.

Importantly for our purposes, the first round of redistribution (2007-2008) happened just before the central government issued Government Regulation 74/2008 which made it compulsory for teachers to teach 24 hours face-to-face to be eligible for the professional allowance. In contrast to District A, then, redistribution does not appear to have been conceived from the outset as a way of ensuring that teachers receive the professional allowance. Rather technocratic concerns seem to have had a more significant influence reflecting two factors. The first relates to the personal capacities of the district's bupati from 2005 to 2015. Several informants described the bupati as 'educated' and 'capable of thinking'. The second factor is his apparent political strategy of seeking legitimacy for his education policies by securing the support of international donors. Under his rule, District B became home to a wide range of donor education projects including Bermutu, Prodep, and a UNICEF project on school-based management. As we note below, this meant that local education officials had access to technocratic ideas and policy solutions concerning teacher distribution at a crucial moment.

The politics of teacher redistribution proceeded in eight main stages.

- First, the bupati was elected in 2005 on the basis of promises to transform District B into a 'Clever District' (Kabupaten Cerdas). Teacher redistribution was not explicitly part of this agenda at this point. His five-year development plan for 2005-2010 identified education as a priority sector but made no mention of teacher redistribution. ${ }^{60}$

- Second, the government of District B applied for and was selected to be part of a World Bank-MoEC pilot study on teacher management. This study dealt with, among other things, issues of teacher distribution (see World Bank and MoEC 2010). This introduced the regional government, in particular the education agency, to relevant technocratic ideas. ${ }^{61}$

- Third, recognizing that the bupati was open to ideas for reform-indeed, in all likelihood demanding them-education agency officials carried out a mapping of teacher distribution within the district and presented the results to him. ${ }^{62}$

- Fourth, education agency officials began to 'socialize' teacher redistribution among parliamentary representatives through working group meetings (rapat kerja) with members of the DPRD committee (Komisi 2) responsible for education. ${ }^{63}$

- Fifth, teacher redistribution was carried out in 2007-2008. This precipitated a lot of complaints, many of which were directed to the DPRD. According to the DPRD representative that we interviewed, the DPRD held firm, having agreed to the policy. ${ }^{64}$ The Bermutu project started in 2008-District B was one of the project's pilot regions. This project focused mainly on teacher training but also had a component related to the development of a teacher database.

- Sixth, teacher redistribution was subject to challenge in the local state administrative court (PTUN) around 2008-2009 (the dates are a little unclear). Only a small number of teachers were involved in the PTUN case (between 1 and 3 depending on the source of

\footnotetext{
${ }^{60}$ Interviews with the current head of education agency in District B who was the head of the Basic Education branch in the mid-2000s, District B, July 2015; and the former rector of the local state university (former IKIP). District B, August 2015.

${ }^{61}$ We wish to thank Susi Iskandar for her advice on this point.

${ }^{62}$ Interview with the head of education agency in District B, July 2015.

63 Interview with a member of Komisi 2, District B, July 2015.

${ }^{64}$ Interview with a member of Komisi 2, District B, July 2015.
} 
information). The case was expensive: for instance, it entailed flying in experts from Gadjah Mada University and elsewhere and hiring lawyers. This suggests that the teachers had financial support from other sources. Who backed the dissident teachers is unknown. However, several informants suggested that their motivation was to damage the bupati in the run-up to the 2010 district head and 2011 gubernatorial elections, so the backer may have been a rival politician or one of his supporters. In any event, they lost the PTUN case: the court found in favor of the government of District B.

- Seventh, the district government introduced an isolated areas allowance (tunjangan daerah terpencil) figuring that this would reduce resistance in the future.

- Eighth, the district government passed a regional regulation (perda) and series of bupati regulations (perbup) to provide a regulatory framework for teacher management and constrain future governments.

\subsubsection{Summary}

In sum, then, the four cases above illustrate that teacher redistribution has posed significant political challenges for regional governments, explaining why-in the context of no credible threat of sanctions from above-most regional governments have baulked at addressing teacher distribution problems. At the same time, however, they also illustrate that redistribution has been possible where:

- as in District A, mid-level government officials, especially ones at the local education agency, have judged that reform initiatives can be exploited for patronage purposes; secured support from above; and devised effective strategies for managing the politics of reform (by, for instance, securing the support of the DPRD and buying off the losers from reform);

- as in District B, reform-minded district leaders have been elected providing an imperative for education agency officials to design reform programs and they have access to relevant ideas and policy advice; or

- as recently in Municipality B, the central government has devised and implemented policy instruments that, accidently or otherwise, provide regional governments with an incentive to carry out teacher redistribution;

\subsection{School Mergers and Multigrade Teaching}

The entrenched nature of patronage and political networks linking schools to regional governments has also led to inefficiencies with regards to the number of schools and class sizes. It is not uncommon in Indonesia to find several schools sharing the same campus or closely located to one another that have vastly different enrollments and class sizes. This is particularly the case in Java and in urban areas. Education agency officials in our four focus districts suggested that schools with low enrolments have typically been permitted to continue operating as stand-alone entities rather than merged with nearby schools, at least until one of the relevant school principals retires. Likewise, schools have been permitted to maintain small class sizes rather than merge them in order to ensure that class and subject teacher positions are maintained. It has only been when school principals retire that local education agencies have moved to merge schools. At this point, the politics of mergers becomes a lot easier because the patronage and political networks that might potentially oppose reform have little to lose. 
This situation is inefficient to the extent that it results in duplication of work and sub-optimal class sizes. But it has made perfect sense in terms of the logic of the local patronage and political networks linking schools and teachers with the local government. Decisions with regards to the establishment, closure or merger of schools appear to have been driven largely by a desire to create and maintain civil service positions in geographic locations attractive to teachers rather than a concern to ensure equitable access to quality schooling across geographic locations. The challenge of delivering education to students living in remote locations has led to the existence of small schools with small class sizes in these locations. But this is a distinct problem that in fact reflects some attempt by government to address equity issues.

For the most part, governments in our four focus regions had done little to address these problems through the implementation of either school mergers or multigrade teaching. In District A, for instance, the local education agency carried out a mapping (pemetaan) exercise in 2006-2007, that identified 172 primary schools as suitable (layak) for mergers. In November 2012 letter, the then head of the education agency asked the bupati to issue a bupati decree (SK bupati) providing for the merger of four schools in one sub-district. ${ }^{65}$ Another 10 schools were merged in 2015, although it was not clear where. ${ }^{66}$ In interview, the then head of the education agency said that the education agency had adopted a softly-softly approach in relation to school mergers, carrying out socialization first and then waiting for the schools concerned to indicate that they are interested in merging. ${ }^{67}$ It often still waits until school principals retire before merging schools. The agency has also introduced multigrade teaching but it has done so only in a small number of schools, mainly in isolated areas. ${ }^{68}$

Municipality A has been a little more successful in carrying out school mergers but only a little more so. Independent teacher groups and NGOs have called for school mergers since the early 2000 s ${ }^{69}$ propelling the city government to introduce a program of school mergers at primary school level around 2007. But this program has progressed very slowly. The key reason appears to be an expectation on the part of senior government officials that mergers would generate a backlash from school principals, teachers and local communities. In 2009, the then head of the city education agency told the media that school mergers 'could not be done quickly because everything has to fit with the needs and conditions in the field including recruitment of school principals, the retirement age of school principals and other matters so that it does not cause a shock (gejolak) in the field'. ${ }^{70}$ In May 2015, the current head of the education agency in announced that the city government would merge two-thirds of the 800 primary schools deemed to fall into the above categories. It remains to be seen how quickly it will act on this policy.

In Municipality B, school mergers have also been uncommon. However, recently the local government has engineered some mergers of both public and private schools to ensure class sizes are sufficient to enable the teachers responsible for the relevant classes to meet certification requirements. ${ }^{71}$

\footnotetext{
${ }^{65}$ Interview with the current head of the District A Education Agency, June 2015.

${ }^{66}$ Interview with senior education agency officials, District A, June 2015.

${ }^{67}$ Interview, District A, June 2015.

${ }^{68}$ Interview with senior education agency officials, District A, June 2015.

${ }^{68}$ Interview, District A, June 2015.

${ }^{69}$ Interview with FAGI/FGII activist, Municipality A, May 2015.

${ }^{70}$ Reference withheld because it identifies the municipality.

${ }^{71}$ Interview with the current head of the Municipality B Education Agency.
} 
One issue with regards to school mergers is how mergers would impact on honorary teachers (guru honor). In interview, the current head of the Honorary Teachers Communication Forum (FKGH), an organization representing honorary teachers, argued that school mergers had in some cases resulted in honorary teachers losing their livelihoods (although he also indicated that so far FKGH has sought to address this issue through efforts to seek redress at the school level-including by threatening to take matters to the State Administrative Court, PTUNrather than by opposing school mergers as policy).

In sum, then, the issue of school mergers and multigrade teaching illustrates clearly the political limits to teacher management reform. In this case, reform has only occurred when patronage and political networks have stood to lose little from reform and it has consequently been easy in political terms.

\section{Conclusion}

Indonesia faces serious problems with regards to teacher numbers and cost, teacher quality and teacher distribution. This report has sought, using a political economy framework, to explain the origins of these problems, identify the political obstacles to teacher management reform, and specify the political conditions under which the country has made progress in promoting reform.

With regards to the first two of these matters, we have argued that these problems have their origins in the way in which political and bureaucratic elites have for decades used the school system to accumulate resources, distribute patronage, mobilize political support, and exercise political control. Under this system of school management, teachers have been incorporated into patronage and political networks the logic of which has been to position them as clients, vote mobilizers, and agents of political control and rather than agents of education and equity. While government technocrats and their donor supporters have endeavored to promote a range of teacher management reforms embodying an alternative logic-namely, improving educational outcomes with maximum budgetary efficiency - they have generally lacked the political power to have a significant impact. The collapse of the New Order in the late 1990s created a political context more conducive to reform by undermining the economic base of New Order elites and their corporate clients and enhancing the structural power of donors. But the continued political dominance of elements nurtured under the new Order at both the national and local levels of government has ensured that the results of reform initiatives have so far been modest, although technocrats and donors have managed to achieve some wins.

With regards to the conditions under which reform has been possible, the report has pointed to five sets of conditions: namely when 1) the central government has had at its disposal or been able to devise policy instruments that are effective in disciplining local governments and it has maintained a commitment to these policy instruments even in the face of opposition; 2) local civil society groups are present and able to launch effective public campaigns demanding reform, exploiting their ability to access the independent media and, if necessary, the courts; and local governments have been able to find effective ways of buying off losers from reform; 3) mid-level government officials, especially ones at the local education agency, have judged that reform initiatives can be exploited for patronage purposes; secured support from above; and together with senior officials devised effective strategies for managing the politics of reform; 4) reform-minded district leaders have been elected providing an imperative for education agency officials to design reform programs and the latter have had access to relevant 
ideas and policy advice as a result of contact with donors; and/or 5) teachers and the patronage and political networks of which they are part have stood to lose little from reform.

Broadly speaking, these findings suggest that technocrats and donors' strategy for promoting further teacher management reform in Indonesia should incorporate five components. We label these respectively the 'disempowerment' component, the 'disciplinary' component, the 'working with the grain' component, the 'activism' component, and the 'facilitative' component. Each component is underpinned by a different theory of change and entails a different set of policy interventions. The different components can be thought of as lying along a spectrum - in the order listed above-according to the degree of direct central government intervention they imply (Figure One). At one end of the spectrum, the disempowerment component entails more or less total central government control over policy and implementation. At the other end of the spectrum, the facilitative component entails the central government supporting district government steps towards teacher management rather than seeking to precipitate change from above. Each component should also be thought of as appropriate for particular political contexts at the local level. Specifically, the facilitative component is appropriate for contexts where reform-minded leadership exists at the local level and the task is accordingly to help change along. The other components, by contrast, are for employment in contexts where such leadership has not yet emerged and the political challenge is to precipitate change, potentially in the face of resistance.

\section{Figure One}

\section{Component Spectrum}

\begin{tabular}{|c|c|c|c|c|}
\hline $\begin{array}{l}\text { Extensive and } \\
\text { direct central } \\
\text { government } \\
\text { intervention }\end{array}$ & & & & $\begin{array}{l}\text { Limited and } \\
\text { indirect } \\
\text { central } \\
\text { government } \\
\text { intervention }\end{array}$ \\
\hline Disempowerment & Disciplinary & $\begin{array}{l}\text { Working with } \\
\text { the grain }\end{array}$ & Activist & Facilitative \\
\hline
\end{tabular}

The Disempowerment Component

The purpose of this component is to reduce the ability of political and bureaucratic elites and the patronage and political networks they control, particularly ones at the regional level, to resist teacher management reform by transferring authority over the implementation of teacher management policy to the central government. It presumes that shifting authority over teacher management to the central level will in general produce better teacher management decisions by placing decision-making authority in the hands of officials who do not have direct personal relationships with the teachers concerned and/or are not part of the local patronage and political networks that link schools with local education agencies. In terms of the policy initiatives we have analyzed above, the recent changes to civil service recruitment provide a model of how this component of the strategy can work. It would be useful to extend this initiative to the selection of school principals and perhaps teacher transfers/distribution (although the latter could also be addressed through other components). The process employed for teacher recruitment provides a template that could be used to devise a similar system for school principal selection while the establishment of Dapodik means that the central government now has the data required for it to manage teacher transfers. 
There are three questions in relation to this approach. The first is whether such changes are politically possible given that, under the country's decentralization laws, responsibility for education policy lies with local governments and local political and bureaucratic elites have a clear incentive to oppose any loss of power. The fact that teacher recruitment has been reappropriated by the center suggests that it may be. The second is whether transferring greater authority to the central government level would simply see a relocation of the patronage- and politically-oriented behavior that has shaped school principal promotions and teacher transfers to that level. The available evidence so far in relation to the operation of the new civil service recruitment system would suggest that this need not occur. The final question relates to the central government's willingness to take on responsibility for school principal promotions and teacher transfers. This cannot be assumed, particularly if central government officials see assuming such responsibility as a burden. ${ }^{72}$

\section{The Disciplinary Component}

The purpose of this component is to alter the incentives that political and bureaucratic elites at the regional level face with regards to teacher management reform by presenting regional governments with a credible threat that they will be punished if they do not implement teacher management reforms and/or a credible commitment that they will be rewarded if they do. It presumes that the central government has the political will to design and enforce effective policy instruments or, if it does not, the ingenuity to devise alternative ones to which it can credibly adhere. In terms of the policy initiatives we have analyzed above, the central government moratorium on new civil service appointments constitutes the model to be replicated (although district-level concerns about a looming teacher crisis suggest that an alternative basis for imposing the moratorium—e.g. teacher-student ratios-may be necessary). The teacher certification program and SKB 5 Menteri illustrate the risk that weak central government commitment poses to the effectiveness of such instruments. But, in the case of the latter, they also illustrate the potential for such instruments to be reinvented in a potentially more effective form: at the time of writing, the central government is reportedly preparing a government regulation replacing the SKB 5 Menteri that offers financial rewards to regional governments that implement teacher management reforms rather than imposes sanctions on those that do not (Suara Karya 2015). The crucial issues with regards to this new regulation will be whether the financial inducement on offer to regional governments is sufficient to precipitate change in the way in which local political and bureaucratic elites approach teacher management and the central government remains committed to providing rewards in the face of any concern about their budgetary impact.

\section{Working with the Grain Component}

The purpose of this component is to promote teacher management reform by exploiting opportunities presented by the certification program, in particular, the financial incentive it has created for teachers to move schools in order to meet certification requirements, to replace school principals, and carry out school mergers. This component presumes that teacher

\footnotetext{
${ }^{72}$ For instance, provincial governments (which represent the central government in the regions) do not appear to have been overly thrilled with at least some of the additional powers over the school system recently invested in them by Law 23/2014 on regional governance. This law transfers authority over senior secondary schools from district-level governments to provincial governments. It also gives provincial governments authority to address teacher distribution issues across districts. In interview, two provincial government representatives indicated that they were interpreting the latter power as applying only to the distribution of teachers at senior secondary level, not the primary and junior secondary levels as well (Interviews in Municipality A and Municipality B). It is possible that provincial governments have taken this position because they simply do not want the headache of dealing with redistributing teachers at these lower levels given that there are many more teachers employed at these levels than at the senior secondary level.
} 
management reform is easier when it accords with or, at least, does not fundamentally contradict the logic underpinning local patronage and political networks - it is in that respect that it is about 'working with the grain' ${ }^{73}$ The fact that teacher redistribution in District A was driven predominantly by a concern to ensure that teachers met certification requirements and only secondarily by a concern to improve educational equity and quality suggests that the former concern is a more powerful precipitant of change than the latter. So, too, does Municipality B's response to the introduction of more stringent technical guidelines for the professional allowance, the recent moves by Kota Goronalo and District B to implement school principal periodization, and Municipality B's experience with school mergers.

For government technocrats and donors, this in turn suggests a need to reappraise their so far overwhelmingly negative view of the certification program (see, for instance, Chang et al 2014; World Bank 2015). While certification may so far have produced little benefit in terms of its ostensible objective - to improve teacher subject knowledge and pedagogical skills - it may just be the key to solving other teacher management problems and, in particular, those related to teacher distribution, school principal tenure, and school mergers. The certification program is probably here to stay, notwithstanding its weaknesses and considerable impact on the government budget, because the political cost to elites of axing it or even significantly reducing its financial benefits for teachers would be high. Technocratic officials and donor agencies may as well make use of it to promote a more equitable and efficient distribution of teachers, regeneration in school leadership positions, and efficiencies through school mergers. In this respect, they should think about the way in which the incentives created by the certification program might dovetail with other central government processes to shift incentives for reform at the local level. Municipality B's experience suggests that linking the certification program to state audit processes, for instance, may be one particularly promising way forward in this respect.

\section{The Activism Component}

The purpose of this component is to alter the incentives that political and bureaucratic elites at the regional level face with regards to teacher management reform by empowering local proponents of reform through the provision of financial, moral or other forms of support. This component presumes that local proponents of reform exist at the local level and that they have the capacity to apply pressure on the local government to implement reform by accessing the local media or courts. It also presumes that they would be more effective in these respects if better resourced and connected to more powerful actors. As we have seen above, there has been some support for teacher management reform —or at least some specific reforms-within the NGO community and among independent teacher organizations. Yet such organizations generally exist only in major urban centers with substantial middle classes, independent media, and strong civil society movements, not in predominantly rural districts, small municipalities or remote areas. Municipality A's experience vis-à-vis the periodization of school principals illustrates the potential that these groups have to promote reform. But the fact that they tend to exist only in major urban centers is a key constraint. Another is the fact that these groups have generally been critical of the technocratic and donor agenda in relation to education policy, particularly anything seen as embodying neoliberal principles, making partnerships difficult.

\section{The Facilitative Component}

As noted above, the purpose of this component is to facilitate teacher management reform in regions where the political preconditions for reform are already in place because the local

\footnotetext{
${ }^{73}$ See Kelsall (2008) for a broader discussion of the notion of 'working with the grain'.
} 
leadership is supportive of reform. In these cases, technocrats and donors do not need to find ways of forcing or cajoling local elites into adopting teacher management reforms. Rather they simply need to provide them with ideas for reform and political cover and legitimacy by offering support. Among policy initiatives we have analyzed above, the World Bank and Dutch Embassy's support to District B through the pilot teacher management study and then the Bermutu project provide the best example of this component in action. The key constraint to this approach is that reformist leadership such as that in District B appears to be very rare and may not endure where it emerges. For this reason, proponents of reform should consider taking advantage of 'moments' of reformist leadership to enact local regulations (perda) providing for the reform. Such regulations will not constrain future governments where the local legislature and executive oppose teacher management reform - in these cases, they will simply overturn the regulations. But they may where opinion is divided.

\section{Putting the Components Together}

There are numerous different ways in which these various components might be assembled to produce an overall strategy for promoting teacher management reform in Indonesia. The key constraints in this respect is that the disempowerment component cannot be used in conjunction with any of the other components because it implies direct central government control while the other components imply that district-level governments have primary responsibility for decision-making and the task of central government is accordingly to influence their decisionmaking. Otherwise, however, the components are not mutually exclusive and could be used to devise multi-pronged approaches to addressing specific problems. Table One below summarizes one way in which these components might be assembled to address various teacher management problems based on the analysis above. We have omitted teacher certification from the table because it is a predominantly central government-run scheme.

\section{Table One}

\section{Proposed Use of Strategy Components}

\begin{tabular}{|c|c|c|c|}
\hline $\begin{array}{ll}\text { Problem } & \text { Strategy } \\
\end{array}$ & Component 1 & Component 2 & Component 3 \\
\hline Teacher Numbers and Cost & $\begin{array}{c}\text { Disciplinary } \\
\text { Continued use of } \\
\text { moratorium, possible } \\
\text { extension of moratorium } \\
\text { to all regions using } \\
\text { teacher-student ratio as } \\
\text { basis for imposition }\end{array}$ & & \\
\hline $\begin{array}{l}\text { Teacher Employment and } \\
\text { Promotion }\end{array}$ & $\begin{array}{c}\text { Disempowerment } \\
\text { Continued use of new } \\
\text { civil servant recruitment } \\
\text { process, extension to } \\
\text { school principal } \\
\text { promotions }\end{array}$ & & \\
\hline $\begin{array}{l}\text { Teacher Distribution } \\
\text { - Option } 1\end{array}$ & $\begin{array}{l}\text { Disempowerment } \\
\text { Centralization of } \\
\text { decision-making over } \\
\text { teacher placements }\end{array}$ & & \\
\hline - Option 2 & $\begin{array}{c}\text { Disciplinary } \\
\text { New central government } \\
\text { regulations establishing } \\
\text { credible threats/rewards }\end{array}$ & $\begin{array}{l}\text { Working with the grain } \\
\text { Linking certification } \\
\text { program incentives to } \\
\text { state audit processes } \\
\text { and other central }\end{array}$ & $\begin{array}{c}\text { Facilitative } \\
\text { (cases with reform- } \\
\text { minded leadership } \\
\text { only) }\end{array}$ \\
\hline
\end{tabular}




\begin{tabular}{|c|c|c|c|}
\hline & $\begin{array}{l}\text { to create new incentives } \\
\text { at the district level }\end{array}$ & $\begin{array}{l}\text { government } \\
\text { mechanisms }\end{array}$ & $\begin{array}{l}\text { Provision of } \\
\text { technical advice, } \\
\text { ideas, legitimacy }\end{array}$ \\
\hline $\begin{array}{l}\text { Periodization of School } \\
\text { Principals }\end{array}$ & $\begin{array}{l}\text { Working with the grain } \\
\text { Linking school principal } \\
\text { tenure to certification } \\
\text { program incentives }\end{array}$ & $\begin{array}{c}\text { Activist } \\
\text { Supporting NGOs and } \\
\text { teacher groups } \\
\text { campaigning for } \\
\text { periodization }\end{array}$ & $\begin{array}{c}\text { Facilitative } \\
\text { (cases with reform- } \\
\text { minded leadership } \\
\text { only) } \\
\text { Provision of } \\
\text { technical advice, } \\
\text { ideas, legitimacy }\end{array}$ \\
\hline $\begin{array}{l}\text { School Mergers and } \\
\text { Multigrade Teaching }\end{array}$ & $\begin{array}{l}\text { Working with the grain } \\
\text { Linking school } \\
\text { mergers/multigrade } \\
\text { teaching to certification } \\
\text { program incentives }\end{array}$ & $\begin{array}{c}\text { Activist } \\
\text { Supporting NGOs and } \\
\text { teacher groups } \\
\text { campaigning for } \\
\text { school mergers }\end{array}$ & $\begin{array}{c}\text { Facilitative } \\
\text { (cases with reform- } \\
\text { minded leadership } \\
\text { only) } \\
\text { Provision of } \\
\text { technical advice, } \\
\text { ideas, legitimacy }\end{array}$ \\
\hline
\end{tabular}




\section{References}

Al Samarrai, S. et al (2012) Making Better Use of Teachers: Strengthening Teacher Management to Improve the Efficiency and Equity of Public Spending, Jakarta: World Bank.

Amelia R. (2012) ‘Angelina Faces 20 Years in Jail as Bribery Trial Begins’, Jakarta Globe, 7 September.

APINDO (2014) Stengthening Business Competitiveness For a Prosperous Indonesia: Findings from APINDO's 2014 Survey on Business Competitiveness in ndonesia, Jakarta: APINDO.

Aspinall, E. (2014) 'Health Care and Democratization in Indonesia', Democratization, 21 (5), pp.803-823.

Ayuningtias, R. (2012) 'FSGI Nilai Uji Kompetensi Guru Bentuk Malpraktek', Tribun News, 1 August, available at: http://www.tribunnews.com/nasional/2012/08/01/fsgi-nilai-ujikompetensi-guru-bentuk-malpraktek, accessed 14 September 2015.

Balikpapanpos (2014) '2015, Anggaran Tunjangan Profesi Guru Capai Rp80 Triliun', 21 October, available at: http://www.balikpapanpos.co.id/berita/detail/138484-2015-anggarantunjangan-profesi-guru-capai-rp80-triliun.html.

Batampos (2014) 'Putri Bupati Bintan Ansar Ahmad Tak Lulus Tes CPNS', available at: http://batampos.co.id/27-12-2014/putri-bupati-bintan-ansar-ahmad-tak-lulus-tes-cpns/, accessed 13 November 2015.

Beteille, T. (2009) Absenteeism, Transfers and Patronage: The Political Economy of Teacher Labor Markets in India, unpublished PhD dissertation, Stanford University.

Bjork, C. (2003) 'Local Responses to Decentralization Policy in Indonesia', Comparative Education Review, 47 (2), pp.184-216.

Boediwardhana, W. (2011) 'Civil Servant Recruitment Moratorium Opposed', Jakarta Post, 6 September, p.5.

Buehler M. (2009) 'Decentralisation and Local Democracy in Indonesia: The Marginalisation of the Public Sphere,' in E. Aspinall and M. Mietzner (eds.) Problems of Democratization in Indonesia: Elections, Institutions and Society, Singapore: ISEAS.

Chang, M., S. Shaeffer, S. Al-Samarrai, A. Ragatz, J. de Ree, and R. Stevenson (2014) Teacher Reform in Indonesia: The Role of Politics and Evidence in Policy Making, Washington DC: World Bank.Gaynor, C. (1998) Decentralization of Education: Teacher Management, Washington DC: World Bank.

Grindle, M. (2004) Despite the Odds: The Contentious Politics of Education Reform, Princeton: Princeton University Press.

Grindle, M. (2007) 'Reform Despite the Odds: Improving Quality in Education', Rev. Pensiamento Educativo, 40 (1), pp.131-152. 
Guharoy, D. (2008) 'Without Quality Education, The Country Will Change Fundamentally,' Jakarta Post, 4 March.

Hadiz, V. (2003) 'Reorganizing Political Power in Indonesia: A Reconsideration of So-called 'Democratic Transitions’, Pacific Review, 16 (4), pp.591-611.

Hadiz, V. (2010) Localizing Power in Post-Authoritarian Indonesia: A Southeast Asia Perspective, Stanford: Stanford University Press.

Hameiri, S. (2007) 'Failed States or Failed Paradigm? State Capacity and the Limits of Institutionalism', Journal of International Relations and Development, 10, pp.122-149.

Hudson, D. and A. Leftwich (2014) From Political Economy to Political Analysis, Canberra: Developmental Leadership Program.

Ilfiyah, A., F. Hendri, R. Rasiki, and R. Yudhistira (2015) Kegagalan Pemerataan Guru: Evaluasi SKB 5 Menteri Tahun 2011 Tentang Penataan dan Pemerataan Guru PNS di Indonesia, Jakarta: ICW.

Irawan A., Eriyanto, L. Djani, and A. Sunaryanto (2004) Mendagangkan Sekolah, Jakarta: Indonesia Corruption Watch.

Jakarta Post (2011) ‘Govt to Cap Local Budgets for Personnel’, 14 September, p.13.

Jalal F. and B. Musthafa (eds.) (2001) Education Reform in the Context of Regional Autonomy: The Case of Indonesia, Jakarta: MoNE, Bappenas, and World Bank.

Jalal F, M. Samani, M. Chang, R. Stevenson, A. Ragatz, and S. Negara (2009) Teacher Certification in Indonesia: A Strategy for Teacher Quality Improvement, Jakarta: MoNE, World Bank, and Dutch Embassy.

Jawa Pos (2014) 'Empat Daerah Sukses Program Pemerataan Guru', 14 October, available at: http://www2.jawapos.com/baca/artikel/8100/empat-daerah-sukses-program-pemerataan-guru.

Kelsall, T. (2008) Going With the Grain in African Development? Africa Power and Politics Discussion Paper No 1, London: Overseas Development Institute.

King, D. (1995/6) 'Bureaucracy and Implementation of Complex Tasks in Rapidly Developing States: Evidence From Indonesia’, Studies in Comparative International Development, 30 (4), pp.78-92.

Kingdon, G. and M. Muzammil (2009) 'Political Economy of Education in India: The Case of Uttar Pradesh’, Oxford Developmemt Studies, 37 (2), pp.123-144.

Kompas (1970) ‘PGRI Bernaung Dibawah Sekber Golkar’, 11 July.

Kompas (2002) 'Penerimaan CPNS di Daerah Bernuansa KKN', 14 November, p.19.

Kompas (2010b) 'PGRI Desak Surat Edaran Menpan Dicabut', 26 November.

Kompas (2010b) 'SKB Redistribusi Guru Disiapkan', 9 June, available at: http://edukasi.kompas.com/read/2010/06/09/20065384/SKB.Redistribusi.Guru.Disiapkan, accessed 14 September 2015.Kompas (2015a) ‘Kualitas Guru Masih Rendah’, 8 July, p11. 
Kompas (2015b) 'PGRI: Moratorium CPNS Berdampak Pada Krisis Guru', 5 July, available at:

http://edukasi.kompas.com/read/2015/07/05/14184321/PGRI.Moratorium.CPNS.Berdampak. pada.Krisis.Guru, downloaded 16 September 2015.

Lampost.co (2013) 'Wapres: Perbaiki Cara Rekrutmen PNS Dengan Obyektif', available at: http://lampost.co/berita/wapres-perbaiki-cara-rekrutmen-pns-dengan-obyektif, accessed 17 September 2015.

Leftwich, A. (2010) 'Beyond Institutions: Rethinking the Role of Leaders, Elites and Coalitions in the Institutional Formation of Developmental States and Strategies,' Forum for Development Studies, 37 (1), pp.93-111.

Leslie, S. and J. Strudwick (2015) Education Partnership Annual Partnership Performance Report: Management Response, available at: https://dfat.gov.au/aboutus/publications/Documents/2014-indonesia-education-annual-parthership-performancereport-management-response.pdf, accessed 21 September 2015.

Liputan6.com (2012) 'Gugat Uji Kompetensi Guru ke MA', available at: http://m.liputan6.com/news/read/429859/gugat-uji-kompetensi-guru-ke-ma, accessed 14 September 2015

Manggiasih, B. (2013) 'Rekrutmen PNS Pintu Masuk Korupsi', Tempo.co, 4 December, available at: http://nasional.tempo.co/read/news/2013/12/04/173534672/rekrutmen-pns-pintumasuk-korupsi, accessed 17 September 2015.

McKenzie, P. et al (2014) Study on Teacher Absenteeism in Indonesia 2014, Jakarta: ACDP.

McKinsey and Co (2012) The Archipelago Economy: Unleashing Indonesia's Potential, McKinsey and Co.

McLeod, R. (2000) ‘Soeharto’s Indonesia: A Better Class of Corruption’, Agenda, 7 (2), pp.99112.

Mulkeen, A. (2010) Teachers in Anglophone Africa: Issues in Teacher Supply, Training, and Management, Washington DC: World Bank.

Mustakim (2015) 'Retno Listyarti, Guru Pejuang Pendidikan', available at: http://m.news.viva.co.id/news/read/615290-retno-listyarti--guru-pejuang-pendidikan/2, accessed 14 November 2015.

Padmawati (2010) Kajian Yuridis Status Hukum Tenaga Guru Honorer Pemerintah Kota Surakarta Pada Dinas Pendidikan Pemuda dan Olahraga Kota Surakarta Menurut UndangUndang Nomor 43 Tahun 1999 Tentang Pokok-Pokok Kepegawaian, Skripsi, Fakultas Hukum, Universitas Sebelas Maret Surakarta.

Pahlevi, R. (2012) 'SKB 5 Menteri Rugikan Guru', Inilah.com, available at: http://m.inilah.com/news/detail/1863163/skb-5-menteri-rugikan-guru, accessed 22 September 2015.

PGRI (2015) Teachers Problems and its Solution, position paper. 
Pierskalla, J. and A. Sacks (2015) 'Patronage Cycles: Evidence from Local Elections in Indonesia', available at: https://www.dropbox.com/s/hypuuw0q8bwoq8s/PBC_November_2015.pdf?dl=0, accessed 12 November 2015.

Pikiran Rakyat (2015) 'Masih Banyak Kepsek Duduki Jabatan Lebih Dari 12 Tahun’, 19 Mei, available at http://www.pikiran-rakyat.com/pendidikan/2015/05/19/327796/masih-banyakkepsek-duduki-jabatan-lebih-dari-12-tahun, accessed 18 September 2015.

Pisani, E. (2013) ‘A Nation of Dunces?’ Inside Indonesia, 114 (Oct-Dec).

Prawiro, R. (1998) Indonesia's Struggle for Economic Development: Pragmatism in Action, Oxford: Oxford University Press.

Prodep (2015) “No Title.” available at: http://prodep.kemdikbud.go.id/index.php, accessed 21 September 2015.

Ray, D. and G. Goodpaster (2003) 'Indonesian Decentralization,' in D. Kingsbury and H. Aveling (eds.) Autonomy and Disintegration in Indonesia, London: RoutledgeCurzon.

Reeve, D. (1985) Golkar of Indonesia: An Alternative to the Party System, Singapore: Oxford University Press.

Republika (2014) 'Ini Kabupaten yang Berhasil Melakukan Pemerataan Guru', 20 October, available at: http://www.republika.co.id/berita/nasional/umum/14/10/20/ndpeob-inikabupaten-yang-berhasil-melakukan-pemerataan-guru, accessed 21 September.

Robison, R. (1996) 'The Middle Class and the Bourgeoisie in Indonesia,' in R. Robison and D. Goodman (eds), The New Rich in Asia: Mobile Phones, McDonalds and Middle Class Revolution, London: Routledge: 79-104.

Robison, R. and V. Hadiz (2004) Reorganizing Power in Indonesia: The Politics of Oligarchy in an Age of Markets, London: Routledge.

Rodan G., K. Hewison, and R. Robison (eds) (2006) The Political Economy of South-East Asia: Markets, Power and Contestation, Melbourne: Oxford University Press.

Rosser, A. (2015) 'Law and the Realisation of Human Rights: Insights from Indonesia's Education Sector,' Asian Studies Review, 39 (2), pp.194-212.

Rosser, A. and A. Joshi (2013) 'From User Fees to Fee-Free: The Politics of Realising Universal Free Basic Education in Indonesia’, Journal of Development Studies, 49 (2), pp.175189.

Rosser, A. and J. Curnow 2014 'Legal Mobilisation and Justice: Insights from the Constitutional Court Case on International Standard Schools in Indonesia', The Asia-Pacific Journal of Anthropology, 15 (4), pp.302-318.

Rosser, A. and P. Sulistiyanto (2013) 'The Politics of Universal Free Basic Education in Indonesia: Insights from Yogyakarta’, Pacific Affairs, 86 (3), pp539-560. 
Rosser, A. and I. Wilson (2012) 'Democratic Decentralisation and Pro-poor Policy Reform in Indonesia: The Politics of Health Insurance for the Poor in Jembrana and Tabanan', Asian Journal of Social Science, 40 (5-6), pp. 608-634.

Schiller, J. (1999) 'The 1997 Indonesian Elections: "Festival of Democracy" or "Costly Fiction”', University of Victoria Occasional Paper No 22, May.

Schiller J. (2009) 'Electing District Heads in Indonesia: Democratic Deepening or Elite Entrenchment,' in M. Erb and P. Sulistiyanto (eds.) Deepening Democracy in Indonesia? Direct Elections for Local Leaders (Pilkada), Singapore: Institute of Southeast Asian Studies, pp.147-173.

Setuningsih N. (2012) 'KPK Calls University Heads in Investigation Linked to Angelina, Nazaruddin’, Jakarta Globe, 21 June 21.

Suara Karya (2015) 'Pemerintah Godok PP Pemerataan Guru', available at: http://www.suarakarya.id/2015/03/15/pemerintah-godok-pp-pemerataan-guru.html, accessed 15 August 2015.

Sugiharto, S. (2012) 'Just Remove Competency Test, Trust Teachers', Jakarta Post, 4 August, http://www.thejakartapost.com/news/2012/08/04/just-remove-competence-test-trustteachers.html, accessed 14 September 2015.

Suryahadi, A. and Sanbodho, P (2012) Assessment of Public Policies to Improve Teacher Quality and Reduce Teacher Absenteeism, SMERU Working paper, November.

Tendler, J. (2002) The Fear of Education, Background Paper for Conference on Inequality and the State in Latin America and the Caribbean, Washington, DC: The World Bank.

The Economist (2014) 'Schools In’, 13 December.

Tribun Pontianak (2013) 'Anak Bupati dan Keponakan Istri Bupati Sintang Tak Lulus CPNS', 30 December, available at: http://pontianak.tribunnews.com/2013/12/30/anak-bupati-dankeponakan-istri-bupati-sintang-tak-lulus-cpns, accessed 13 November 2015.

Turner, M. and O. Podger (2003) Decentralisation in Indonesia: Redesigning the State, Canberra: Asia Pacific Press.

UNCEN, UNIPA, SMERU, BPS and UNICEF (2012) “We Like Being Taught”: A Study on Teacher Absenteeism in Papua and West Papua, available at: http://www.unicef.org/indonesia/Teacher_Absenteeism_Study_Papua_ENGLISH.pdf, accessed 22 September 2015.

USAID (2013) Audit of USAID/Indonesia's Kinerja Program, available at: https://oig.usaid.gov/sites/default/files/audit-reports/5-497-14-001-p.pdf, $\quad$ accessed 21 September 2015.

USAID (2014a) Tata Kelola Distribusi Guru Secara Proporsional (DGP), available at: http://www.kinerja.or.id/pdf/242948cf-ebe1-41b8-9dc0-ad052ef35324.pdf, $\quad$ accessed 21 September 2015. 
USAID (2014b) Prioritizing Reform, Innovation, and Opportunities for Reaching Indonesia's Teachers, Administrators, and Students (USAID PRIORITAS) Annual Report, October 2013September 2014, available at: http://pdf.usaid.gov/pdf_docs/PA00KKMD.pdf, accessed 21 September 2015.

USAID Prioritas (2014) 'Berhasil Dalam Penataan dan Pemerataan Guru', Prioritas Pendidikan, October-December, p. 2.

USAID Prioritas (2015) Policy Brief: Teacher Deployment in Indonesia, Jakarta: USAID Prioritas.

Vice President of Indonesia (2011) 'Memanfaatkan Tambahan Anggaran untuk Pendidikan: Wakil Presiden Memimpin Rapat Komite Pendidikan', 13 Juli, available at: http://wapresri.go.id/index/preview/berita/1449.

Widoyoko, D. (2005) 'The Education Sector: The Fragmentation and Adaptability of Corruption' in E. Aspinall and G. Van Klinken (eds.) The State and Illegality in Indonesia, Leiden: KITLV Press.

Winters, J. (2010) Oligarchy, Cambridge: Cambridge University Press.

World Bank (1989) Indonesia: Second Secondary Education and Management Project, World Bank Staff Appraisal Report.

World Bank (1996) Staff Appraisal Report: Indonesia: Secondary School Teacher Development Project, Washington DC: World Bank.

World Bank (1998) Education in Indonesia: From Crisis to Recovery, Washington DC: World Bank.

World Bank (2010a) Transforming Indonesia's Teaching Force: Volume One: Executive Summary, Jakarta: World Bank.

World Bank (2010b) Transforming Indonesia's Teaching Force: Volume Two: From Preservice Training to Retirement: Producing and Maintaining a High-Quality, Efficient, and Motivated Workforce, Jakarta: World Bank.

World Bank (2013) Spending More or Spending Better: Improving Education Financing in Indonesia, Jakarta: World Bank.

World Bank (2014) Indonesia - Better Education through Reformed Management and Universal Teacher Upgrading (BERMUTU) Project, available at: http://documents.worldbank.org/curated/en/2014/06/19789951/indonesia-better-educationthrough-reformed-management-universal-teacher-upgrading-bermutu-project, accessed 212 September 2015.

World Bank (2015) Indonesia: Teacher Certification and Beyond, Report No. 94019-ID, Washington DC: World Bank. 


\section{Annex One}

\section{Table on Case Studies}

\begin{tabular}{|c|c|c|c|c|c|}
\hline \multirow{5}{*}{ District Name } & \multicolumn{4}{|c|}{ Need for Reform } & \multirow[t]{4}{*}{ Reform Initiatives } \\
\hline & & TSR & & & \\
\hline & TSR SD & SMP & & & \\
\hline & $<26$ & $<20$ & $\begin{array}{l}\text { prpnsdist } \\
\text { (median } \\
=.096 \text { ) }\end{array}$ & $\begin{array}{l}\text { jspnsdist } \\
\text { (median = } \\
0.189)\end{array}$ & \\
\hline & 2010 & 2010 & 2010 & 2010 & \\
\hline District B & Yes & Yes & 0.115 & 0.229 & TR, RG, MG \\
\hline District A & Yes & No & 0.114 & 0.168 & Some TR, MG \\
\hline Municipality B & Yes & Yes & 0.079 & 0.153 & $\begin{array}{l}\text { Recently some } \\
\text { period and TR }\end{array}$ \\
\hline Municipality A & Yes & Yes & 0.041 & 0.149 & RG, period \\
\hline
\end{tabular}

Notes: i) TR = teacher redistribution; RG = regrouping of schools; $\mathrm{MG}=$ multi-grade classes; period(isasi) $=$ dismissal of school principals after two terms; ii) prpnsdist and jspnsdist are measures of the extent to which civil servant teachers can be redistributed in a region at the primary and junior secondary levels respectively. 